\title{
Tanzimat Mizahının İki Şehri: İstanbul ve İzmir
}

\author{
Two Cities of Tanzimat Humor: Istanbul and Izmir
}

Gökhan Demirkol, Dr. Öğr. Üyesi, Çankırı Karatekin Üniversitesi Sanat Tasarım ve Mimarlık Fakültesi, E-posta: gokhand06@yahoo.com

https://doi.org/10.47998/ikad.971474

Anahtar Kelimeler:

Türk Basın Tarihi, Mizah Dergileri, İstanbul, İzmir.
Keywords:

Turkish Press

History,

Humor Magazines, Istanbul, Izmir.

\section{$\ddot{O} z$}

Osmanlı Devleti'nde "basın” olgusunun merkezi İstanbul'dur. Özellikle 19. yüzyılda devletin desteği ve denetimi altında gelişen matbaacılık faaliyetleri "gazetecilik" etkinliğinin merkezinin İstanbul olmasında önemli bir etkendir. Bu süreçte 1870 yılından itibaren yayımlanmaya başlayan Türkçe mizah dergileri de ilk olarak İstanbul'da okuyucu ile buluşmuştur. Bu durumun tek istisnası ise Kara Sinan dergisidir. 1875 yılında İzmir'de yayımlanmaya başlayan Kara Sinan dergisi, 1870-1877 yılları arasında İstanbul dışında yayımlanan ilk Türkçe mizah dergisidir. Çalışma, Tanzimat dönemi mizahı olarak adlandırılan 1870-1877 yılları arasında İzmir'de yayımlanan Kara Sinan dergisine karşı İstanbul mizah basınının yaklaşımını tespit etmeyi amaçlamaktadır. İçerik Çözümlemesi yönteminin kullanıldığı bu çalışmada, Kara Sinan dergisinde yer alan İstanbul mizah basını ile ilgili yazılar ve İstanbul mizah basınında Kara Sinan ile ilgili yazılar analiz birimi olarak belirlenmiştir. Çalışma sonucunda İstanbul mizah basını içerisinde sadece Hayal dergisinin Kara Sinan dergisine karşı olumsuz bir tavır sergilediği tespit edilmiş̧ir. Ayrıca İstanbul ve İzmir şehirleri arasında mizah dergilerinin birbirleriyle mesleki ilişkilerin yanı sıra ticari ilişkilerinin de var olduğu gözlemlenmiştir.

The center of the "press" phenomenon in the Ottoman Empire was Istanbul. Especially in the 19th century, the printing activities developed under the support and control of the state are an important factor for Istanbul's being the center of the "journalism" activity. In this process, Turkish humor magazines, which started to be published in 1870, met with readers in Istanbul for the first time. The only exception to this situation is Kara Sinan magazine. Kara Sinan magazine, which started to be published in Izmir in 1875, is the first Turkish humor magazine published outside of Istanbul between 1870 and 1877 . The study aims to determine the approach of the Istanbul humor press against the Kara Sinan magazine, which was published in Izmir between 1870-1877, which is called the humor of the Tanzimat period. In this study, in which the Content Analysis method was used, the articles about the Istanbul humor press in the Kara Sinan magazine and the articles about Kara Sinan in the Istanbul humor press were determined as the analysis unit. As a result of the study, it has been determined that only Hayal magazine among the Istanbul humor press has a negative attitude towards Kara Sinan magazine. In addition, it has been observed that humor magazines have commercial relations with each other as well as professional relations between the cities of Istanbul and Izmir. 


\section{Giriş}

Osmanlı Devleti'nde “basın” kavramının tanımlayıcı mekânı İstanbul'dur. Özellikle basın için temel alt yapıyı oluşturan matbaanın devletin denetimi altında olması matbaacılık ve yayıncılık faaliyetlerinin büyük oranda İstanbul merkezli gelişmesini sağlamıştır. Osmanlı Devleti'nde 1727 yılında başlayan Türk matbaacılığı ancak 1820'li yıllardan itibaren gelişim göstermeye başlamıştır (Serçe, 2000: 4). 1729-1876 yılları arasında İstanbul'daki matbaa sayısının 116 (\% 76,8), İstanbul dışındakilerin 35 (\% 23,2) olduğu ve İstanbul dışındaki matbaaların çoğunluğunun 1864 yılından sonra açılan vilayet matbaaları olduğu (Serçe, 2000: 5-6) dikkate alındığında İstanbul'un merkezi konumu daha net bir şekilde ortaya çıkmaktadır. Matbaa faaliyetlerinin 1820'li yıllardan itibaren gelişim göstermesinde itici güç kuşkusuz "gazete" olgusudur. Üretim faaliyetinin gazete üzerinde yoğunlaşması Osmanlı toplumunda Avrupa'nın aksine bir kitap kültürü yerine gazete kültürünün ön plana çıkmasını sağlamıştır (Koloğlu, 1999: 331). Bu kültürün yaygınlaşmasında devlet eliyle yayımlanan Takvim-i Vekayi ve devlet desteğiyle yayın hayatını sürdüren Ceride-i Havadis önemli bir rol oynamış, toplumda "gazete" ve "basın" olgularına dair bir zemini hazırlayarak toplumun gündelik hayatına bu kavramların yerleşmesinde öncülük etmişlerdir. Bununla birlikte gazete kültürünün şekillendiği şehir olarak İstanbul'un da merkezi konuma gelmesinde etkili olmuşlardır. Bu iki gazete her ne kadar basın adına Osmanlı'da bir zemin oluşturmuş olsalar da halkın merak ve heyecanla takip ettiği Avrupa'da 1848 olayları, 1853 Kırım Savaşı ve 1856 Islahat Fermanı gibi siyasi ve toplumsal olaylarla ilgili haber ihtiyacını karşılamada yetersiz kalmışlardır (İnuğur, 2005: 186). Bu durumun neticesi ise 21 Ekim 1860 tarihinde Türk Basını'nın ilk özel gazetesi Tercüman-1 Ahval'in yayın hayatına başlamasıdır. Tercüman-1 Ahval ile Osmanlı basını Takvim-i Vekayi ve Ceride-i Havadis'in "vakanüvis" çizgisinden "fikir gazeteciliği" çizgisine evrilmeye başlamıştır. Bu çizgi üzerinde gelişen ve çeşitlenen yayınlar toplumsal hayatta "gazete" olgusunun kalıcı bir yer edinmesini sağlamış ve de tematik yayıncılığın gelişiminin önünü açmıştır.

Türk Basın Tarihi içerisinde tematik yayıncılığın en önemli alanlarından birisi olan Türkçe mizah basını da İstanbul'da doğmuştur. 1870 yılında Ali Raşid ve Filip Efendi'nin imtiyaz sahibi olduğu Terakki gazetesinin ilave olarak yayımladığ 1 Terakki dergisi ilk Türkçe mizah dergisi olarak İstanbul'da okuyucu ile buluşmuştur (Demirkol, 2016: 145). Terakki dergisini altı ay sonra Teodor Kasap'ın Diyojen'i takip etmiştir. Türkçe mizah dergilerinin ilk evresini oluşturan Tanzimat Mizahı Dönemi yayınları incelendiğinde bir yayın dışında hepsinin İstanbul'da yayımlanmış olduğu görülmektedir. Türkçe mizah dergileri Türk Basın Tarihi açısından tematik yayıncılık noktasında önemli bir gelişme olmakla birlikte gündelik hayat pratikleri çerçevesinde oluşturulmuş içerikleri ile de önemli yayınlardır. Geleneksel sözlü mizahın anlatı formlarını kullanan bu dergiler "gündelik" olandan beslenmiştir. Bu açıdan 19. yüzyıl Osmanlı toplumun gündelik hayat pratiklerini tespit etme noktasında zengin birer kaynak olarak karşımıza çıkmaktadırlar. Başka bir ifade ile Türkçe mizah dergileri, gündelik siyasi gazetelerin sayfalarına yansımayan ya da kısaca değinilen olayları ve konuları irdeleyerek toplumsal iletişim ağında dolaşıma sokabilmeyi başarmıştır. 
Osmanlı Devleti'nde gerçek anlamda basının başlangıç noktası olarak Agah Efendi'nin Tercüman-1 Ahval' inin kabul görmesine karşın “basın” ve "gazete" olgularının toplumsal hayata entegre edilmesinde Takvim-i Vekayi ile Ceride-i Havadis'in öncü rol oynaması gibi Ermenice ve Rumca mizah dergileri de Türkçe mizah basınının gelişim sürecinde önemli bir rol üstlenmiştir. 1855 yılında yayımlanan Zvarcakhos (Nüktedan) dergisi ilk Ermeni mizah dergisi (Mildanoğlu, 2014: 32) olmakla beraber Osmanlı Devleti'nde yayımlanan ilk mizah dergisi olma özelliğine de sahiptir ${ }^{1}$. Nüktedan Derneği (Zvarcakhos Ingerutyun) tarafından haftalık olarak yayımlanan dergi, Arabyan Matbaası'nda basılmıştır. Dört sayı yayımlanan derginin bazı kısımları Ermeni harfli Türkçe olarak basılmıştır (Mildanoğlu, 2015: 331). Zvarcakhos dergisini 1856 yılında Meğu (Arı) dergisi izler. Ermenice ve Rumca mizah dergilerinin Türkçe mizah yayıncılığına etkisini "yayıncılar" ve "çizerler" başlıkları altında ele almak mümkündür. 1870-1877 yılları arası Diyojen, Çıngıraklı Tatar ve Hayal dergilerini yayımlayan Teodor Kasap, yayıncılar içerisinde en önemli isimdir. Türkçe mizah dergisi Diyojen'den önce Kasap, Rumca O Diogenis isimli mizah dergisini yayımlamıştır (Kut, 2011: 473). 1873 y1lından 1877 yılına kadar yayımladığı Hayal dergisi ise 368 sayı ile Tanzimat Dönemi mizah dergileri arasında en uzun soluklu mizah yayınıdır. Yayıncı olarak Türkçe mizah basınının gelişmesinde etkili olan bir diğer isim ise "Ermenilerin Moliere'i” (Pamukciyan, 2003: 102) Hagop Baronyan'dır. 1874 yılında Tiyatro dergisini çıkaran Baronyan, 1870’de Poğ Aravodyan (Sabah Borusu) isimli Ermenice mizah dergisinin editörlüğünü üstlenmiştir. Ayrıca Harutyun Sıvacıyan'ın Meğu dergisinin de editörlüğünü 1872'den 1874'e kadar yürütmüştür (Bardakjian, 2017: 29). Tiyatro dergisi ile Baronyan Türk Mizah Basını'na tiyatro-mizah ilişkisi üzerine oturtulmuş bir mizah yaklaşımı ve anlatı formuyla önemli katkılar sağlamıştır.

Tanzimat dönemi mizahı herne kadar sözlü mizahın temel anlatı formlarını kullanıyor olsa da karikatür de bu dönemin önemli bir anlatı formudur. Bu noktada da öne çıkan husus çizerlerdir. 1870-1877 yılları arasında yayımlanmış karikatürlerin büyük çoğunluğunun imzasız olması çizerleri tespit etmeyi zorlaştırmaktadır. Ancak tespit edilenler arasında öne çıkan isim Nişan Berberyan'dır. Mizah dergilerine karikatür çizmenin yanı sıra yayıncı ve matbaacı da olan Berberyan'ın eserlerine 1869 yılında Kevork Ayvazyan tarafından yayımlanan Mamul (Basın) dergisinin dışında Türkçe Hayal, Tiyatro, Geveze ve Meddah mizah dergilerinde de rastlamak mümkündür (Çeviker, 1986: 111). Gerek yayıncı gerekse de çizer olarak Ermenice ve Rumca mizah basını 1870 yılından itibaren Türkçe mizah yayıncılığının gelişimine önemli katkı sağlamıştır ve İstanbul bu sürecin temel mekanıdır.

1870 yılından itibaren Türkçe mizah dergisi yayıncılığının tek merkezi olan İstanbul'a 1875 yılında İzmir rakip olarak çıkmıştır. 4 Haziran 1875 tarihinde yayın hayatına başlayan Kara Sinan dergisi, İzmir'in ilk Türkçe mizah dergisi olmanın yanı sıra İstanbul dışında yayımlanan ilk Türkçe mizah dergisi de olmuştur.

1 Literatür tarafından Osmanlı Devleti’nde yayımlanan ilk mizah dergisi Boşboğaz Bir Adem olarak gösterilmektedir. Ancak son dönem yapılan çalışmalar Boşboğaz Bir Adem'in bir süreli yayından ziyade bir risale olduğunu ortaya koymuştur (Bkz. Vartanyan, 2017). 
Bu çalışmanın amacı; İstanbul'da yayımlanan Türkçe mizah dergilerinin İzmir'de yayımlanmış olan Kara Sinan dergisi ile olan ilişkilerini tespit etmektir. Bu kapsamda; "İstanbul merkezli Türkçe mizah basını İstanbul dışında yayımlanan bir Türkçe mizah dergisininasılkarşılamıştır?” "İkişehirdekiTürkçemizahbasınınınbirbirleriyleilişkilerinin niteliği nedir?” ve “İzmir'de Türkçe mizah yayıncılığının gelişiminde İstanbul'da etkili olan unsurlara rastlamak mümkün müdür?” sorularına cevap aranmaktadır. Bütünlüklü bir Türk Basın Tarihi ortaya konulabilmesinin farklı şehirlerde ortaya çıkmış yayınların birbirleriyle ilişkilerinin incelenmesi ile mümkün olabileceği varsayımından hareket eden çalışma, Kara Sinan dergisinin yayın hayatı ile sınırlandırılmıştır. Çalışmada İçerik Analizi yöntemi kullanılmıştır. Bu kapsamda Kara Sinan dergisinde İstanbul mizah basını ile ilişkili metinler ve Kara Sinan'ın yayın hayatını sürdürdüğü tarihlerde İstanbul'da yayımlanan Hayal, Geveze, Letâif-i Âsar, Tiyatro, Kahkaha, Latife, Meddah ve Çaylak'ta tespit edilen Kara Sinan'la ilişskili metinler analiz birimi olarak belirlenmiştir. İstanbul ve İzmir mizah basını arasında ilişkisel bir çalışmanın literatürde yer almaması çalışmayı önemli k1lan unsurdur.

\section{İzmir Basını ve İzmir’in İlk Türkçe Mizah Dergisi Kara Sinan}

Osmanlı Devleti'nde basının kalbinin attığı yer İstanbul olsa da toplumun "gazete" olgusu ile tanışmasında önemli katkı sağlayan bir diğer şehir İzmir'dir. Bu katkının ilk adımı 24 Mart 1821 tarihinde Alexandre Blacque tarafindan yayımlanan Fransızca Spectateur Oriental gazetesidir (İnuğur, 2005: 168). Haftalık olarak yayımlanan gazete dört sayfadan oluşmaktadır (Arıkan, 1985: 103). Spectateur Oriental'i 1824'de Le Smyrneen ve 1828'de Le Courrier de Smyrne gazeteleri izlemiştir (Sevinçli, 2019: 39). İzmir'de 19. yüzyılın ilk yarısında Fransızca basının yanı sıra Rumca basının da geliştiği görülmektedir. Rumca basının ilk örneği 1831 yılında yayımlanan O Files Ton Neon gazetesidir (Sevinçli, 2019: 39). Gerek Fransızca gerekse de Rumca basının geliştiği İzmir'de Türkçe basın 1869 yılında Aydın gazetesinin yayımlanması ile başlamıştır. Türkçe basının İzmir'de 19. yüzyılın ikinci yarısında doğuşunun altında yatan etken ise Osmanlı Devleti'nin mahalli idareler alanında "eyalet" sisteminden "vilayet" sistemine geçmesidir. 1864 yılında hayata geçen bu düzenleme sonrası vilayet merkezlerinde birer matbaa kurulmuş ve resmi "vilayet gazeteleri” yayımlanmaya başlamıştır (Varlık, 1985: 99). İzmir'de Türkçe basının ilk örneği olan Aydın gazetesi de Aydın Vilayeti'nin resmi vilayet gazetesi olarak bu sürecin bir ürünüdür. Aydın gazetesinden sonra ilk özel teşebbüs ürünü Türkçe gazete ise 1872 yılında yayımlanan Devir gazetesidir (Sevinçli, 2019: 80). Mehmet Salim'in imtiyaz sahibi olduğu Devir gazetesini Ermeni asıllı avukat Kevork Bubliyan'in (bilinen ismi ile Corci Bubli) 1875 yılında yayımladığı İntibah gazetesi izlemiştir (Huyugüzel, 1996: 53).

Türkçe basın için yaklaşık yarım asır bekleyen İzmir, Türkçe mizah basını ile İstanbul'dan kısa bir süre sonra, 1875 yılında Kara Sinan dergisinin yayımlanması ile tanışmıştır. İlk sayısı 4 Haziran 1875 (29 Rebiülahir 1292) tarihinde yayımlanan Kara Sinan'ın imtiyaz sahibi Karidi ya da tam adıyla Grigorios Karydis'dir. Haftada bir Perşembe günleri yayımlanan dergi 4 sayfaya 3 sütun hazırlanmış ve serlevhasında 
nüsha bedeli “40 para” olarak belirlenmiştir. İzmirni Matbaası'nda basılan Kara Sinan'ın idari merkezi de aynı yerdir. Altı aylık abone bedeli "1 sim mecidiye", bir yıllık abone bedeli ise "2 sim mecidiye" olarak serlevhasında belirtilmiştir. Faruk Huyugüzel, Kara Sinan'ın 35 sayılık bir yayın hayatı olduğunu ve 16 Mart 1876 (19 Safer 1293) tarihinde kapandığını belirtmektedir (1996: 54-55). Derginin günümüze ulaşan 23 nüshasının ${ }^{2}$ sonuncusu 3 Mart 1876 (6 Safer 1293) tarihli 30 numaralı nüshadır. Kara Sinan'ın yayın periyodu dikkate alındığında Huyugüzel'in derginin kapandığını belirttiği 16 Mart 1876 tarihi 32. sayıya denk gelmekte iken 35. sayının tarihi 6 Nisan 1876 (11 Rebiülevvel 1293) tarihine denk gelmektedir. Mevcut koleksiyonların 30. sayı ile bitiyor olması bu tarihleri doğrulamayı zorlaştırmaktadır.

Derginin içeriği ağırlıklı olarak İzmir'in gündelik hayatı (ulaşım, altyapı sorunları, eğitim, eğlence hayatı vb.) ve İzmir basınına ilişkin metinlerden oluşurken İstanbul basını hakkında da yazılar yer almaktadır. İçeriğin bir unsuru olarak her sayıda bir adet karikatüre de yer verilmiştir. Çizer imzası bulunmayan bu karikatürlerde konu seçimleri İzmir'deki gündelik hayatı temel almakta ve eğitim, ulaşım, eğlence hayatı, alafrangalık, tüketim mallarındaki fiyat artışları ve İzmir basını gibi konular öne çıkmaktadır. Üslup noktasında perspektif kullanımı, ışı ve gölge detaylarına dikkat edilmesi ile figürlerin oranlarında gerçekçiliğin tercih edilmesi bu karikatürlerin çizerinin klasik resim eğitimi almış olma ihtimalini akla getirmektedir. Genel olarak Kara Sinan dergisinde yer alan karikatürlerin İstanbul'da yayımlanan bazı mizah dergilerindeki karikatürler ile kıyaslandığında daha profesyonel oldukları söylenebilir.

Derginin imtiyaz sahibi olan Yunanlı Karidi hakkındaki bilgiler sınırlıdır. 1856 yılında Türkiye'ye veya İzmir'e geldiği tahmin edilen Karidi'nin bir ruhban okulunda eğitim aldığı düşünülmektedir. Yayıncılık hayatına kiliseye ait Efsevia gazetesi ile başlayan Karidi, 1870'de Zmirni gazetesini çıkarmıştır. Zmirni gazetesinin 1876 yılında kapanması üzerine aynı yıl Nea Zmirni gazetesini ve 1877'de de İzmir isimli bir Türkçe gazete yayımlamıştır. Karidi'nin Kara Sinan'dan önce, 1874 yılında Velos isminde Rumca bir mizah dergisi de yayımladığı bilinmektedir (Huyugüzel, 2000: 163-164). Rumca ve Türkçe yayınların yanı sıra Karidi'ye 1872-1874 yılları arasında Aydın gazetesinin de sorumluluğu verilmiştir (Serçe, 2002: 21). 1881 yılında İzmir'den ayrılan Karidi, İstanbul'a gelmiş ve burada Neologos gazetesinin yayınını üstlenmiştir (Huyugüzel, 2000: 164). Kara Sinan'da yer alan yazıların imzasız oluşu Karidi'nin imtiyaz sahibi olmasının dışında dergiye nasıl bir katkı sağladığını tespit etmeyi imkansız hale getirmektedir. $\mathrm{Bu}$ durum aynı zamanda derginin yazar kadrosunu da belirlemeyi zorlaştırmaktadır. Ancak dergi içeriğinde yazar olarak bir isme rastlanmaktadır: "(...) zira onaltı numaralı İntibahında muharririmiz Emin Efendinin tecennün eylediğini ilân ettikten başka (...)" (Kara Sinan, 20 Ağustos 1875: 3). Metinde adı zikredilen Emin Efendi hakkında dergide başka bir bilgi bulunmamaktadır ancak Huyugüzel, Emin Efendi'yi derginin başyazarı olarak aktarmaktadır (1996: 54). Derginin yazar kadrosunda yer aldığı aktarılan bir diğer isim ise Cemal Bey'dir. 1884 yılından sonra İzmir'de polis müdürlüğü de yapan Cemal Bey, Kara Sinan dergisinde kaleme aldığı yazı ve şiirler sebebiyle "Kara Sinan Cemal Bey" olarak tanınmaktadır (Huyugüzel, 2000: 111).

2 Kara Sinan dergisinin günümüze ulaşan 23 nüshasının sıra numaraları şöyledir: 1, 2, 3, 4, 5, 6, 7, 8, 9, 10, 11, 12, 13, 14, $15,16,18,21,23,24,26,27$ ve 30 . Bu 23 nüshadan 5 ve 10 numaralı nüshalar hariç diğerlerine İSAM ve Hakkı Tarık Us Koleksiyonu’ndan ulaşmak mümkündür. İ.B.B. Atatürk Kitaplığı’nda ise derginin 1. sayısından 10. sayısına kadar olan nüshalarına ulaşılabilmektedir. Milli Kütüphane'de ise sadece 11 numaralı nüsha yer almaktadır. 


\section{İstanbul Karşısında Taşra: İzmir Mizah Basını}

Tanzimat mizahı olarak tanımlanan 1870-1877 yılları arasında İstanbul dışında ya da taşrada mizah basınını temsil eden İzmir'in Kara Sinan dergisi, 4 Haziran 1875 (29 Rebiülahir 1292- 22 Mayıs 1291) Perşembe günü yayımlanmaya başlamıştır. Dergi ilk sayısında çıkış amacını şu şekilde tanımlamaktadır:

Gazetelerin mehâsin-i mülkümüzde zuhûrundan beri efkâr-1 âleme bahş ettiği tesirât-1 bedîsiyle müsbet bulunduğundan mahal-i be mahal çıkarılmakta olan gazetelerin evvel-i mebhasda nakş-1 yerâa-1 belâgatı olan mukaddemât-1 âliyyesi lüzûm ve ehemmiyetini yeniden bast u tafsile hacet bırakmamıştır Şu kadarki tabiat-1 beşeriye meyl-i teceddüd üzere mecbûl olduğundan gazetenin makasad-1 asliye ve fevâ'id-i mahsûsasını istifade ale'd-devam bir tarafa gitmek istemeyip ara sıra kırtas Hayale sebt-i mezâmin Letâif-i Âsar ile mutâyebe-perdazlık havalarını aradığından Dersaadette çıkarılmakta olan eğlence gazetelerine bu garazda müşâreket ve taşra matbuatına müsâbakat hevesiyle İzmirde dahi (Kara Sinan) namıyla böyle bir gazete neşrine mübaşeret olundu (Kara Sinan, 4 Haziran 1875: 1)

Yazının ilk kısmında "gazete" olgusunun Osmanlı toplumu açısından olumlu bir gelişme olduğunun altını çizen dergi, İstanbul'da yayımlanan mizah dergilerine katkı sağlama ve taşrada da matbuata bir rekabet havası getirme amacıyla yayımlandığını ifade etmektedir. Kara Sinan'ın yayımlanması ile İstanbul'da yayımlanan mizah dergilerine katkı sağlanacağı belirtilirken sadece Hayal ve Letâif-i Âsar dergilerinin isimleri telaffuz edilmektedir. Oysa ayn tarihte İstanbul'da Hagop Baronyan'ın Tiyatro'su, Zakarya Beykozlıyan'ın Latife'si, Basiretci Ali Efendi'nin Kahkaha's1 ve Meddah mizah dergileri de yayımlanmaktadır. Karidi'nin Hayal ile Teodor Kasap'1 ve Letâif-i Âsar ile de Mehmet Tevfik'i İstanbul mizah basınının merkezine koymasında bu iki ismin mizah dergisi yayıncılığında sahip oldukları deneyimin ağır bastığı söylenebilir. Türkçe mizah dergiciliği kariyerine Diyojen ile başlayan Teodor Kasap, Çıngıraklı Tatar dergisini ve sonrasında da Hayal dergisini yayımlamıştır. Terakki'den sonra ikinci Türkçe mizah dergisi olan Asır'ın Eğlence İlavesi'ni yayımlayan Mehmet Tevfik, Letâif-i Âsar'ı önce 1871-1872 yıllarında daha sonra da 1874-1875 yıllarında iki kere yayımlamıştır. 18701875 yılları arasında mevcut yayıncılar ile kıyaslandığında bu iki ismin öne çıkması ve Karidi tarafından İstanbul mizah basını ile özdeşleştirilmesi normaldir ${ }^{3}$. Metinde yer alan taşra matbuatına rekabet havası getirme düşüncesi öncelikle Türkçe bir mizah dergisine sahip olmayan İzmir'e bu anlamda katkı sağlamanın yanı sıra İzmir'de Türkçe yayımlanan Aydın ve İntibah gazetelerine Türkçe bir mizah dergisi ile rakip olmayı kapsamaktadır. Aydın gazetesinin vilayet gazetesi olması ve giderlerinin resmi makamlar tarafindan karşılandığ1 düşünüldüğünde rekabetin tek odağ1 İntibah gazetesidir. 1875 yılında İzmir'de yayımlanan tek Türkçe gazete olarak İntibah'ın Kara Sinan tarafından -farklı kulvarlarda yer almalarına karşın- kendisine rakip görülmesinin altında yatan etken ise İntibah gazetesinin başyazarı Mehmet Salim’dir. Ermeni asıllı avukat Corci Bubli (Kevork Bubliyan) imtiyazında yayımlanan İntibah gazetesinin başyazarı Mehmet Salim ile Karidi arasındaki gerilimin kaynağı Aydın gazetesinin sorumluluğunun Mehmet Salim'den alınarak Karidi'ye verilmesidir (Serçe, 2000: 21). Kara Sinan'da yer alan Mehmet Salim

3 Metinde dikkat çeken unsur Hayal dergisi için kullanılan "kırtas" tanımlamasıdır. "Kağıt" anlamına gelen "kırtas" kelimesi ile adını Karagöz oyunundan alan dergiye oyunun temel unsuru olan "perde" üzerinden bir gönderme yapılmaktadır. Bu göndermenin kaynağı ise yine Hayal dergisidir. Hayal, ilk sayısında mukaddimesini bir Karagöz oyunu şeklinde düzenlemiş ve oyunun giriş kısmında yer alan perde gazeli bölümünde kullanılan “Perdeyi sanma bizden kemalattır perdemiz" mısrasını "Perdeyi sen sanma bezden kâğıttandır perdemiz" şeklinde değiştirmiştir (Bkz. Hayal, 30 Ekim 1873: 1; perde gazelleri için ayrıca bkz. And, 1977; Oral, 1996). 
ve İntibah gazetesi hakkındaki yazılar bu iki isim arasında yaşananların gerilim sınırını aşarak husumete dönüştüğünü göstermektedir". Bu noktada "taşra matbuatına müsâbakat" ifadesi ile tek bir gazetenin değil İzmir basınının kast edildiği itirazında bulunulması mümkündür ancak Karidi'nin Velos isminde Rumca bir mizah dergisi yayımladığı ve bu dergi ile taşra matbuatı içerisinde yer aldığı düşünüldüğünde rekabetin oluşacağı yeni bir alan olan Türkçe süreli yayın alanında "müsâbakat" hedeflediğini söylemek mümkündür.

Kara Sinan, ilk sayısında yer verdiği bu metin ile varlığını hem İzmir'e hem de İstanbul'a "olumlu" mesajlar ile duyurmuştur. Bu mesajlara İstanbul'dan ilk yanıt Letâif-i Âsar'dan gelmiştir: "İzmirde Kara Sinan namıyla bir eğlence gazetesi zuhûr etmiş ve birinci nüshası görülmüş olmakla bazı fikraları alınmıştır (...)" (Letâif-i Âsar, 12 Haziran 1875: 3). Bu ibareden sonra dergi, Kara Sinan'1n birinci sayısında yer alan “fıkra çömleğinden” başlıklı kısmı iktibas etmiştir. Kara Sinan'ın yayımlanmasına Teodor Kasap ve Hayal dergisi ise Letâif-i Âsar kadar olumlu yaklaşmamış, 156. sayısında Hayal dergisi Kara Sinan ve özellikle de Karidi hakkında uzun bir metin yayımlamıştır:

Papaz efendileri sever misiniz? Ben çok severim. Hepsinin dua ve hüsn-ü nazarları üstümde olsun. Lakin hayf!! ki bu dünyada her kulun bir tekini olduğu gibi her güruhun içinde bazıda çürük adamlar bulunur. Mesela papaz kısmı ale'l-umûm iyi iseler de bazı kere hava-i nefsâniyyeye tâbi olurlar. Ez-cümle İzmirde (Peder Gigoryos Karidis) cenabları... mûmâileyh gayet tuhaf bir papaz efendidir. Duası isteyenlerin üzerinde olsun. Yunanlıdır... Duası değil kendisi. Bu zat evvelce bir manastıra girerek ebnâ-yı cinsinin günahlarının afv olunması için Cenab-1 Hakka niyaz etmekte idi. Her nasılsa bir gün şeytan bunun karnına girer... Ama siz diyeceksiniz ki manastırda şeytan olur mu ki bunun karnına girsin? Hakkınız var belki manastıra girmezden evvel karnında imiş. Ne hal ise şeytanın ağusuyla böyle bir güzel tariki terk edip kaçmış İzmire gitmiş. Gitmiş ama papaz makulesi adam İzmir gibi bir memlekette saçı sakalı ile suculuk losdıracılık veyahut buna mümasil sanatlar yapamaz a tüccarlık marangozluk ebniye kalfalığı gibi işlere ise hiç girişemez. Ne yapsın biçare kalkar gazeteci olur. İbtida ahaliye ilim öğretmek için Rum lisanı ve Zimir ismiyle bir gazete neşrine başlar. Bakar ki İzmir ahalisini az vakit zarfinda alim etmeye bir gazete kifayet etmeyecek bir taraftan da soytarılık yani güldürüp eğlendirmekle ahalinin ahlaklarını 1slah etmek üzere (Velos) yani ok isminde diğer bir gazete neşrine mübaşeret eder. Ve bu gazetenin başına (hani bir resim lazım a) elinde ok ile yaylı ve başı boynuzlu bir şeytan resmi kor (herifin şeytana meyili ziyade görünüyor) bu şeytanın önünde küre-i arzı tersim eder ve üzerine de yalancılık müdâhenlik mürâyalık âlâyiş nümayiş hırsızlık zina kıskançlık ve bu gibi bir takım ef'âl-i mezmûnenin esamesini iri yazılarla yazar ve bunların beherinin üzerine de enf-i elbeyan şeytan tarafından atılmış birer ok resmi gösterir.

Karagöz beyefendinin işi gücü yok a. Bunun ilk numrosunu gördüğü anda gülmekten bayılarak kalkar Rumca nüshasında buna yazar ki aman papaz efendi sen yapıyorsun? Bu günahlar şeytanın aletidir insanlara bunlarla galebe eder şimdi şeytana sen kendi silahlarını kırdırıyorsun muradın nedir? Böyle şeytanları sen nereden getirdin? Manastırdan $\mathrm{m}$ getirdin? Bu bizim bildiğimiz şeytanlara benzemiyor sen bunu gazetenin başından kaldır mealde birçok nasihatler verir. (Peder Gigoryos Karidis) Efendi Karagözün mektubunu okuduğu anda pancar gibi kızarır. Limon gibi sararır. Kömür gibi kararır. Kar gibi beyazlanır. Muazzam sakalı aziz bıyığına muhterem kaşları mükerrem saçlarına karışır. Kızar tutuşur ağzının ters tarafını açar Karagöz Beyefendiye söver sayar. Hasılı bey Karagöz Efendiyi gülmekten bayıltır. (güzel eğlence ama hayflar olsun ki Türkçe nüshamızı okuyan zevata da sabık Panosyan ahbarı perazanti ettiğimiz gibi bunu da perazanti edemeyeceğiz)

Siz ne zann ediyorsunuz? Bu dünyada yalnız Basiret çelebi mi tâlilidir. Hayır karagözün tâlini biz kimsenin tâliyle değişmeyiz. Mûmâileyh (Peder Gigoryos Karidis) efendi cenabları (duası Zenup Ağanın üzerinde olsun) bir sene sonra geçenlerde karagöz efendinin nasihatını dinleyerek soytarı gazetesinin başından șeytanı kaldırıp düz yazı koymuștur. Papazların bazıları inat olur söz anlamaz bu da o güruhtan imiş. Söz anladı ama neden sonra. Her ne ise anlasın da. Peder Gigoryos Karidis Efendi İzmir gazetesiyle âkılâne ve Velos gazetesiyle câhilâne yani soytarılıkla İzmir ahalisini ıslah edemiyor imiş gibi kalkar geçenlerde Aydın vilayetinin resmi gazetesini de deruhte eder. Şimdi oldu mu üç. Bu

4 Mehmet Salim’in Karidi’nin yazdıklarına dair nasıl bir tutum aldığını ne yazık ki İntibah gazetesinin hiçbir nüshasının günümüze ulaşamamış olmasından dolayı tespit etmek imkânsızdır. Ancak İntibah gazetesi ile ilişkili İlave-i İntibah isminde bir nüshanın Osmanlı Arşivi'nde tespit edilmesi ve içerik olarak Kara Sinan ile Karidi'yi hedef alması iki isim arasındaki ilişkinin boyutunu "husumet" olarak tanımlamaya dayanak oluşturmaktadır (bkz. Demirkol, 2021) 
da kafi gelmez. Bu kere de Kara Sinan isminde Türkçe olarak bir soytarı gazetesi daha çıkarır. Ve İzmir Hıristiyanlarını güya 1slah ettiği yetişmezmiş de şimdi Müslümanlarını da ıslaha başlar. Allah safâ-i hatır versin papaz gazeteci merakınız mıdır? Merakınız ise alınız bakınız gazetesinde ne yazmış. Ben aldım okudum gülmekten bayıldım. İsterseniz bir parçacığını buraya derç edeyim de sizde görünüz

Etmek

"Buğday ve arpa ve darı unlarına suyun mezci ve biraz toz izafesiyle tahmir edilip firınlarda pişirilir en iyisi has franculadır. Etmek çarşıda yapılırken içine bazı çavdar ve delice gibi şeylerde konulur ve bazen hamur olarak çıkarılır pişmiş etmeki insan karnı acıktığı vakit yemek bulursa etmekle beraber akl eder karn doyurucu güzel ve mübarek bir şeydir arpa etmeki bazı şeye bahanedir"

Şu sözlerin hepsi güzel doğru papaz ağzına yakışır ama şu en sonraki bahane lakırtısını anlayamadık..... Bilemiyoruz bu da papaz ağzına yakışır mı? bilen varsa bize de öğretsin.

Aman Allahım bu meslekte şayan-1 istihza daha neler göreceğiz!!! (Hayal, 15 Haziran 1875: 2-3)

Hayal dergisi tarafindan yayımlanan bu metin bir anlamda Karidi'nin “tercüme-i hal"i yani özgeçmişi niteliğini taşımaktadır. Ruhban eğitimi almış olması üzerinden “papaz” tanımı yapılan Karidi’nin özellikle Rumca yayımladığı Velos (Ok) dergisi ve derginin serlevhasında yer alan şeytan figürü üzerinde durulmaktadır.

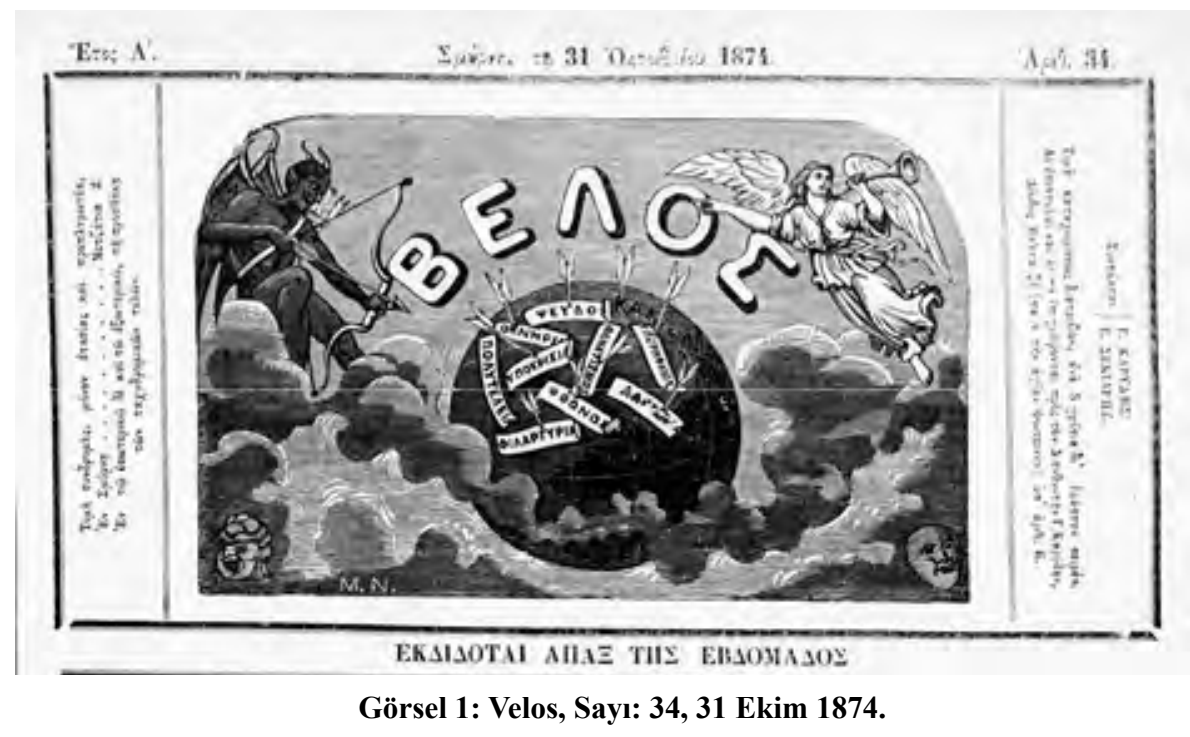

Karidi tarafindan haftada bir yayımlanan Velos, 16 Mart 1874 tarihinde yayın hayatına başlamıştır. Hayal dergisinin belirttiği gibi Velos'un serlevhasının sol tarafında yayı ve okları ile bir şeytan figürü bulunmaktadır (Bkz. Görsel 1). Şeytan figürünün karşısında, serlevhanın sağ tarafında ise bir melek imgesi yer alır. Melek ve şeytan figürlerinin ortasında bulunan dünya imgesinin üzerinde de şeytan tarafindan atılan oklar ile tutturulmuş ПO $\Lambda$ TE $\Lambda$ EIA (lüks), ФI $\Lambda \mathrm{O} \triangle \mathrm{O} \Xi I A$ (hırs), $Ф \Theta O N O \Sigma$ (imrenme), YПOКРІ $\Sigma$ IA (ikiyüzlülük), $\Psi Е Y \Delta \mathrm{O} \Sigma$ (yalan), ФANATI $\Sigma \mathrm{MO} \Sigma$ (fanatizm) ve ҮПЕРНФАNIH (gurur) kelimeleri görülmektedir. Bu serlevha Hayal dergisinin de belirttiği gibi yaklaşık bir yıl sonra 8 Mayıs 1875 tarihinde yayımlanan 45. sayı ile değişmiştir (Bkz. Görsel 2). 


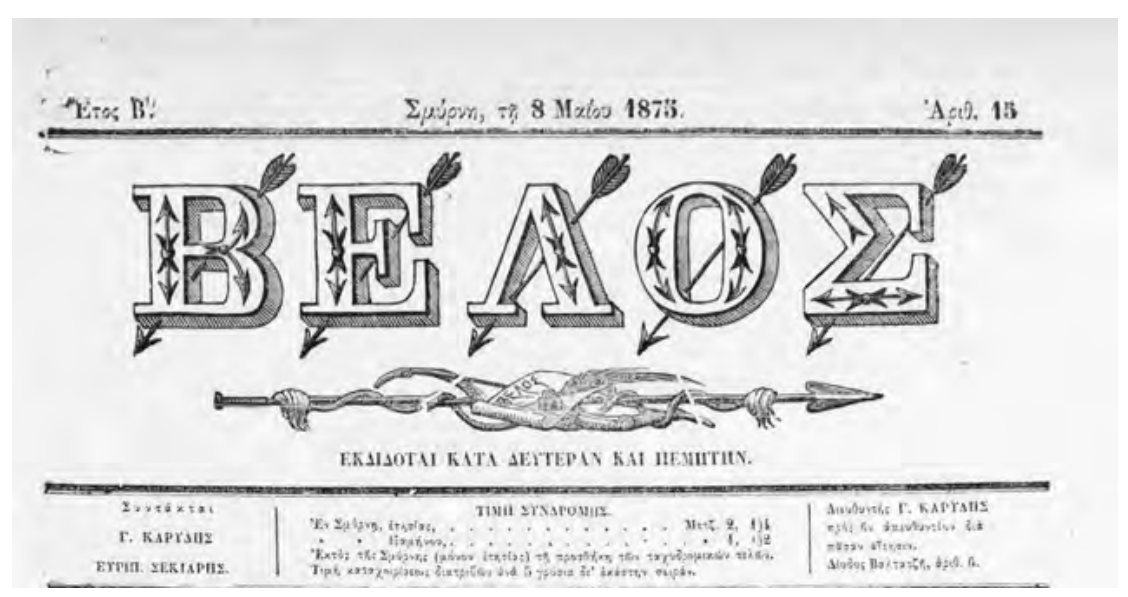

Görsel 2: Velos, Sayı: 45, 8 Mayıs 1875.

Velos dergisinin ilk serlevhasının Karidi'nin ruhban eğitimi ile örtüştüğü görülmektedir ki Hayal dergisi bu örtüşmeyi "papaz" tanımlamasının yanı sıra "şeytan" figürü ile de vurgulamıştır. Karidi'nin Velos ile başlayan mizah dergisi yayıncılığını Kara Sinan ile devam ettirmesini Hayal dergisi "soytarılık" tabiri ile tanımlar. Tanzimat mizahında "soytarı" veya "mashara (maskara)" tabiri ciddiyetsizlik, işini layıkıyla yapamama gibi durumları ifade etmek için tercih edilen kalıplardır. Osmanlı' da mizah dergiciliği temel olarak salt komik ve gülünç üzerine değil sözlü mizah geleneğinden devralınan "güldürürken düşündürmek" veya "kıssadan hisse" almak mantığı ile formüle edilebilecek bir anlayış ile biçimlenmiştir. Gazetecilik pratikleri ile birleşen bu anlayış içerisinde yapılan iş her ne kadar "gülme" üzerine kurulu olsa da ciddi bir iştir ve bu çerçevenin dışında kalan her eylem "soytarılık" olarak nitelendirilir. Hayal'in Kara Sinan için bu tabiri kullanmasının dayanağını ise yazı içerisinde Kara Sinan'dan yaptığı alıntı oluşturmaktadır. Bu alıntı ile İzmir' in ilk Türkçe mizah dergisinin içerik olarak dönem mizah basınının "hakim mizah" anlayışını karşılayamaması Hayal dergisine göre "soytarı" olarak nitelendirilmesi için yeterlidir.

Kara Sinan dergisinin İstanbul mizah basınına dair kaleme aldığı ikinci metin ise 3. sayısında yer almaktadir:

$$
\text { İstanbuldan telgraf }
$$

Kara Sinanın mızrağı buraca bazı gazetelerde mûceb dehşet oldu

\section{Keza}

Bil-ittifak gazeteniz aleyhine yürütmek üzere İstanbul mizah gazeteleri beyninde ve izzetlü Ali Efendinin taht-1 riyasetinde bir komisyon teşkil olunacağı söyleniyor. Fakat bu ittifaka Letâif-i Âsar meşguliyet-i haziresi cihetiyle bi-taraf kalacakmış (Kara Sinan, 17 Haziran 1875: 4)

Hayal dergisinde yer alan yazıdan iki gün sonra yayımlanan bu metin Kara Sinan'ın İstanbul mizah basınına karşı sergilediği “olumlu” tavrın mizah çerçevesinde devam ettiğini göstermektedir. Telgraf formunda kaleme alınan metinde Kara Sinan yayımlanmasını "mızrak" metaforu ile tanımlamış ve mızrağın İstanbul mizah basınında korkuya sebep olduğunu belirtmiştir. Metinde bu metaforun seçilmesi derginin kendisini ve yaptığı işi 
tanımlamak için "mızrak" tabirini kullanmasına dayanmaktadır: "(...) efendim fakiriniz buncazımı böyle elimde tutar kendi kendime mülahazam ne ise onunla uğraşırım bu sırada sinirime dokunacak bir şeyi görüverecek olursam (...) mızrağımla usulacak dokunurum (...)" (Kara Sinan, 4 Haziran 1875: 2). Ayrica derginin serlevhasinda bulunan resim ile de Kara Sinan ve mızrağı görsel hale getirilmiştir. Metinde, mızrağın yani Kara Sinan'ın varlığının İstanbul' da büyük bir korkuya sebep olması ve bu korkunun yayıncıların bir araya gelerek Kara Sinan'a karşı bir komisyon oluşturmasına yol açtığının belirtilmesi İstanbul mizah basınına dair derginin sergilediği "olumlu" tavrın mizah çerçevesini oluşturmaktadır. Dönemin başta gelen mizah dergisi yayıncıları Teodor Kasap, Hagop Baronyan ve Basiretçi Ali Efendi'nin değil bir komisyon oluşturmaları bir mekanda yan yana gelmeleri bile imkansızdır. Yayımlamış oldukları Hayal, Tiyatro ve Kahkaha dergilerinde birbirleri hakkında yazdıkları yazıların bazen rekabet sınırlarını aşması bu durumu teyit etmektedir. Özellikle de Teodor Kasap ve Hagop Baronyan'ın Güllü Agop ile Osmanlı Tiyatrosu konusunda karşı cephelerde yer alması düşünüldüğünde (Bardakjian, 2017: 223-224) Karidi'nin Kara Sinan ile hiçbir şekilde bir araya gelmeyecek kişileri bile bir araya getirecek derecede İstanbul'a korku saldığını ima etmesi mizah çerçevesinde değerlendirilebilecek bir yaklaşımdır. Bu noktada Letâif-i Âsar'ın metinde bahsedilen komisyonun dışında bırakılması ise Mehmet Tevfik ile Karidi arasında olumlu bir ilişkinin varlığını göstermektedir ki Kara Sinan'ın yayın hayatına başladığını İstanbul okuyucusuna haber veren tek mizah dergisinin Letâif-i Âsar olması bu iyi ilişkiyi teyit eden unsurdur.

Karidi ile İstanbul mizah basını arasındaki olumlu ilişkilerin sadece Mehmet Tevfik ve Letâif-i Âsar ile sınırlı kaldığını Kara Sinan dergisinin 4. sayısından sonra Hayal ile yaşadığı polemik göstermektedir. Kara Sinan, Hayal'ın yayımladığı Karidi'nin “tercüme-i hal"ine varlığının İstanbul mizah basınına "korku saldığı" iddialarını yineleyerek 4. sayısında cevap vermiştir:

- Yahu Kara Sinan İstanbul gazetelerini mütalaa edebiliyor musun

- A canım vakit mi bulabiliyorum ben kendi işimle meşgulüm vakit nerede

- Aman Hayal gazetesi seninle nasıl eğlenmiş nasıl eğlenmiş görsen

- Eğlenebilir ya Hayal dediğin mashara gazetesi değil mi bâhusus Karagöz Bey Efendi Ağa hazretleri sayfiyesinde kara yele karşı süpürge bağlarken elbette eğlenecektir sahib-i imtiyazı da şaklabanlıkta karagöz ağadan aşağı kalmaz

- Sahib-i imtiyazı dediğiniz bu zatın kim olduğunu bilemiyorum bu Teodor kimdir bilir misiniz

- Bu zatın asl kasap esnafından idiyse de nargile meraklısı Misailidi çorbacı gibi bakkallara varıncaya kadar gazetecilik edenleri görerek ve bir kasab defteri tutacak malumata güvenerek derhal kasablığ 1 terk ile bir gazete imtiyazı aldı ve adını meşhur alim olan Diyojen koyarak kendisini allame bir filosof saffetinde göstermek istedi sonradan anladı ki öyle kasab kantarıyla filosofluk satılamayacağından ismini tebdil ederek tatarlığa başladı. Halbuki şimendiferler filanlar meydanda iken kimsenin tatara ihtiyacı olmadığını derk ile onunda terk etti. Nihayet düşündü taşındı baktı gördü ki böyle filosofluk tatarlık para eder şeyler değil alem masharalık istiyor eğlence arıyor bu karagözcülükte karar verdi. Lakin biçare kasabın ne filosofluğu bir paraya yaradı ve ne de karagözcülüğünden alem gülüp eğlendi. Bendeniz kendisini şahsen tanımam fakat pederiyle aşinalığımız vardır pederini tanırım bu adam kasap esnafindan epeyce servete malik ve tasarrufata riayeti galib bir tuhaf adam olub hati ekonomiye ol derece riayet-i kâmilesi var idi ki kendi kasab olduğu halde hanesi halkı et şöyle dursun işkembeye bile hasret ederler böyle hasis tabiatlı adam o asırda işitilmiş değil idi hasibini tarif edemem o derece hasis o derece hasis ki işkembenin dışını satıp teferruatını çoluk ve çocuklarına nafaka eder ve onlarda bu yolda rızıklanırlar idi 
- Ha şöyle desene bu herifin ağzı onun için bulaşıkça orası bize lazım değil yalnız bunun ağzının kokusu çekilir mi

- Güzel ama ne yapalım biz uzakta bulunduğumuza teşekkür edelim buraya kokunun rubu bile gelmiyor İstanbuldaki komşuları ne yapsınlar zavallı Panosyanın burnunun direği kırıldı kahkahayı dersen kurdeşen illetine uğradı yatıyor biz yine uzakta olduğumuza hamd edelim

- Acaba kahkaha hasta mıdır öyle ise çaresine bakmalı kahkahasız vakit mi geçer

- Evet bu hafta postasıyla bir miktar ilaç göndermek efkarındayım bunun ilacı pek kolaydır

- Bir parça gil-i ermeni alıp içirmelidirler bir şey kalmaz İstanbulda tazesi olmamalı bizim madenci yeni bir gil-i ermeni madeni bulmuş niyetim tazesinden alıp göndermektir

- Var olun Sinan Ağa şu hamiyetinize diyecek yok lakin şu kokunun def-i çaresi yok mu

- Ama uzattın ha olsa yaparlar belediye bu kadar masrafa duçar olmazdı efendim o murdar ağzın nezâfetiçün Karagöz ağadan her gün bin adet meydan süpürgesi mübâyaa ediyorlar biçarenin kamburuna sebep budur fakat sıhhiye tarafından çaresi aranıyormuş bu kadar malumat aldın ya artık benim işim eyvallah (Kara Sinan, 24 Haziran 1875: 2-3)

Muhavere formundaki Karidi'nin cevap yazısı, temel kurgu olarak Hayal'in yazısı ile örtüşmektedir. "Tercüme-i hal" şeklinde tanımlanabilecek bu kurgu içerisinde Kara Sinan Teodor Kasap'ın yayımladığı dergiler hakkında bilgi verdikten sonra Kasap'ın yaptığı işi “mashara”lık olarak tanımlar ki bu noktada Karidi'nin Teodor Kasap'a kendi silahı ile cevap verdiği söylenebilir. Teodor Kasap'ın Karidi için "elinden bir iş gelmediğinden dolayı gazeteci olması"na dair ifadelerine Karidi de Teodor Kasap'ın soyismini işi ile ilişkilendirerek karşılık vermiştir ${ }^{5}$. Hatta bu ilişki üzerinden daha da ileri giderek Teodor Kasap'ın babasının işkembenin dışını satarak "teferruatını” çocuklarına yedirdiğini, Teodor Kasap'ın ağız kokusunun sebebinin çocukluğunda yediği dışkılar olduğunu açıkça ifade etmiştir. Kara Sinan'ın kullandığı bu “ağız kokusu-dışkı" metaforu Hayal'de Karidi hakkında kaleme alınan metne bir tavır koyma ve de Teodor Kasap'ın İstanbul'da diğer yayıncılar ve Garabet Panosyan ile yaşadığı sıkıntılarda kaleminin “ölçüsüzlüğü”ne bir atıf olmakla birlikte dönem şartları açısından ağır bir eleştiri olarak kabul edilebilir. $\mathrm{Bu}$ açıdan iki dergi arasındaki ilişkinin boyutunu "düşmanlık" olarak tanımlamak mümkündür.

Kara Sinan'ın muhaveresinde dikkat çekici bir diğer isim ise Basiretci Ali Efendi' dir. "kahkahayı dersen kurdeşen illetine uğradı yatıyor" ifadesi ile Basiretci Ali Efendi tarafından yayımlanan Kahkaha dergisini kast eden Kara Sinan, Kahkaha'nın 8 Haziran 1875 tarihli 20. sayısında aldığı 3 aylık kapatma cezasını hastalık ile aktararak İstanbul'a ilaç göndereceğini belirtir. $\mathrm{Bu}$ ifadeler Basiret ile Kara Sinan arasında tıpkı Letâif-i Âsar-Kara Sinan arasında olduğu gibi "olumlu” ilişkilerin varlığını göstermektedir. Bu durumu destekleyen bir diğer unsur ise Basiret gazetesinin 1545. sayısında Kara Sinan'ın yayımlanmaya başlamasından dolayı "bu kere İzmirde Kara Sinan namında bir eğlence gazetesi çıkmış olduğundan müessesleri tebrik olunur” (Basiret, 8 Haziran 1875: 1) ifadesiyle tebrik etmesi ve Kara Sinan dergisinin reklamlarını yayımlanmasıdır.

5 Teodor Kasap’ın "Kasap” soyismi ile ilişkili eleştiri biçimi dönem basını tarafından çok sık kullanılan bir yöntemdir. Asıl ismi Theodor Kasapis olan Teodor Kasap’ın babasının asıl mesleği kumaşçlık olup ailesinin ya da kendisinin kasaplık ile bir bağlantısı bulunmamaktadır. (Bkz. Kut, 2011: 473) 


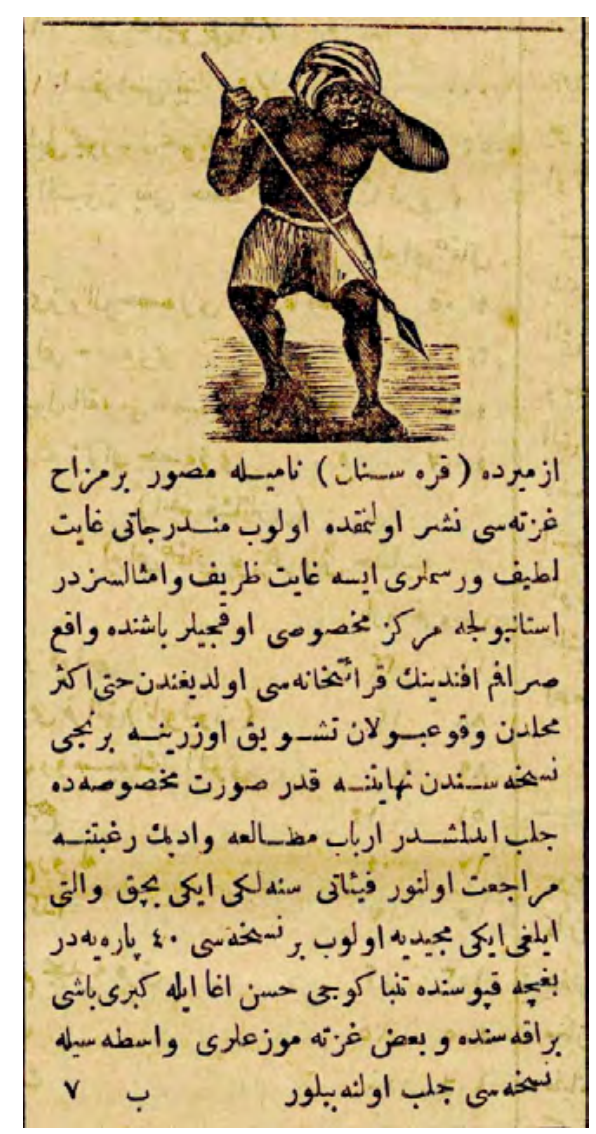

Görsel 3: Basiret, Sayı: 1706, 12 Ocak 1876

Gerek Basiret gazetesinde yayımlanan 8 adet $^{6}$ reklam gerekse de tebrik mesaj1 İstanbul-İzmir hattında Basiret ile Kara Sinan arasında olumlu ilişkilerin yanı sıra ticari ilişkilerin de varlığını göstermektedir.

Hayal dergisinin kendisi hakkında kaleme aldığı yazıya Karidi’nin bir muhavere ile cevap vermesi üzerine Teodor Kasap dergisinin 164. sayısında tekrar Kara Sinan'1 konu edinen bir yazı yayımlar:

Bundan evvelki nüshalarımızın birinde İzmirde gazetecilik etmekte bulunan bir Rum papaz efendisinin tercüme-i halini yazmış ve bu zatın geçenlerde Türkçe lisan ve Kara Sinan ismiyle bir eğlence gazetesi neşrine başladığını söylemiştik.

Resmini görmek isterseniz gazetesini alın bakın. Başına fotoğrafyasını koymuş. Kendisi çırılçıplak aynı bizim Mustafa Baba gibi. Ayağında kısacık bir iç donu başında kara tâkkiye yerine büyükçe bir sarık elinde haç yerine bir mızrak bağ mı depiyor bahçe mi suluyor artık ne yapıyor bilemeyiz...... Papaz efendinin heyet-i kıyafeti pek tuhaftır. Şimdiye kadar çıplak papaz efendi görmeyenlere muayenesini tavsiye ederiz.

Görünüşte bu zat dahi İstanbulda çıkan bazı eğlence gazetecilerinin efkârını tahsin ile bir eğlence gazetesinde muhavere olmadıkça o gazete eğlence gazetesi sayılamaz zannındadır manasız muhavere

6 Kara Sinan reklamları Basiret gazetesinin; 1706, 1707, 1713, 1720, 1725, 1731, 1737 ve 1743. sayılarında dördüncü sayfada yayımlanmıştır. Reklam metni şu şekildedir: "İzmirde (Kara Sinan) namıyla musavver bir mizah gazetesi neşr olunmakta olup münderecatı gayet lâtif ve resimleri ise gayet zarif ve emsalsizdir İstanbulca merkez-i mahsusu Okçular başında vâki Serafim Efendi kıraathanesi olduğundan hâti ekser mahalden vuku' buluna teşvik üzerine birinci nüshasından nihayetine kadar suret-i mahsusada celb edilmiştir erbab-ı mütalaa ve edibin rağbetine müracaat olunur fiyatı seneliği iki buçuk ve altı aylığı iki mecidiye olup bir nüshası 40 parayadır Bahçekapısında tönbekici Hasan Ağa ile Köprübaşı barakasında ve bazı gazete müvezzileri vasıtasıyla nüshası celb olunabilir" (Basiret, 12 Ocak 1876: 4) 
ile bir evet bir yok bir ya bir de öyle mi diyerek satırları geçip sütunları doldurmak kolaydır. İşte bu da o yolu tutmuş. Ama kim kimle muhavere ediyor? Muhaverenin heyet-i mecmuasından maksat ne olabilir? Oralarını düşünüp anlamak için akıl yormak lazım değil... Her ne ise herkes bir yol tutturmuş gidiyor! Biz bahsimize gelelim.

Papaz efendi gazetesini dördüncü numaraya kadar çıkarmış. İkincisini üçüncüsünü görmedik ama dördüncüsünü gördük. Hati tercüme-i halini yazdığımız için kızmış da bazı gönül bulandırır tabirat-1 garibe ve elfaz-1 galize ile bizim aleyhimize dahi birçok yürümüş zırlamış. Gönlü bulanmaksızın okuyacak kadar yiğit varsa papaz efendinin gazetesini alıp okumasını tavsiye ederiz. Ezcümle bir takım işkenbe-i kübraya dair lakırtılar var. Okuyan zevata riâyetimiz olmayaydı mademki İzmirde ve hati İstanbulda bile Basiret sahibi kahkahacı Ali Efendinin gazetesinde bu gibi tabirat neşr olunabildi bizde aynen bu papaz efendinin aleyhimize yazdığı hezeyanı gazetemize derc eder idik. Fakat kahkaha hakkında söylediğimiz sözü tekrar ile kârinemizi tasdîden ihtiraz ederiz. Malumdur ki hezeyan-âmiz bazı türrehat vardır ki muhataba asla dokunmaz belki mütekellime dokunur. Elkelâm suffe-i mütekellim derler.

İstanbul ahalisi Kahkahadaki öyle münasebetsiz tefevvühatdan nefret etmiş idi. Bakalım İzmir ahalisi bu papaz hezeyanından hoşnut olacak mıdır? Şu kadar ki iştihâdan bahs olunamaz! Papaz efendinin Velos namı ve Rum lisanıyla eğlence gazetesi diyerek çıkarmakta bulunduğu ferraşane doldurduğu rezaletlerle İzmirin Rum ahalisinin nefretini kazanmış idi. Zahar bu ceza papaz efendiye elvermemişte Müslümanların nefretini de kazanmak arzusuna düşmüş. Serbesttir. Meslek ittihazı bahs götürmez.

Muharrirlerinin derece-i terbiyesini bilmediğimiz gazeteler ile mübahaseye girişmemekte mâzur olduğumuzu bundan birkaç sene evvel ilan etmiş idik. şimdi bu papaz efendinin derece-i terbiyesini bildiğimiz halde yine hakkında bazı beyanatta bulunduğumuz için evvelki sözümüzün hükümsüzlüğüne hükm olunmasın zira maksadımız ahalinin terbiye-i umumiyyesini ihtilattan vikayeden ibarettir. Papaz efendinin adaba mugayir olarak ağzına yakıştırdığı hezeyanlar bir kere piş-nazar mütalaaya alınsa sükût etmemekte hakkımız her halde tasdik olunur. (Hayal, 3 Temmuz 1875: 2-3)

Karidi'nin hakkında yazdıklarına Kara Sinan dergisinin içeriği üzerinden cevap veren Teodor Kasap, iki olguya odaklanır: serlevha resmi ve muhavere. Kara Sinan dergisinin logosu olarak tanımlanabilecek serlevha resmini Karidi ile özdeşleştiren Kasap, yarı çıplak ve elinde mızraklı bu figürün "tuhaf" oluşunun altını çizer. İçerik noktasında eleştiri getirilen diğer unsur olan muhavereler ise "anlamsız" bulunarak Kara Sinan dergisinin mevcut mizah dergileri standartlarını taşıyamadığı ima edilmektedir. Ortaya konulan ürünün standartları taşıyamaması ise Teodor Kasap'a göre derginin sahibi Karidi'nin meslek erbabı ol(a)mamasının sonucudur. Kendisi hakkında Kara Sinan'ın dile getirdiklerini "gönül bulandıran tabirat-1 garibe ve elfaz-1 galize" şeklinde tanımlayan Teodor Kasap, soyismi üzerinden ailesi ve kendisiyle ilişkilendirilen kasaplık mesleği ile ilgili yorumlara bu mesleğin bir unsuru olan ve de halk arasında "boş konuşmak, dayanaksız konuşmak" anlamına gelen "işkenbe-i kübra" tabiriyle cevap verir. Yazının ilgi çekici kısmı ise Kara Sinan ile Kahkaha arasında kurulan benzerliktir. Bu iki derginin "tefevvühat" yani boşboğazlık noktasında birbirlerinden farkı bulunmadığını ileri süren Hayal, böyle bir üslubun ise okuyucu nezdinde hiç hoş karşılanmadığını da belirtmektedir. Karidi'nin Teodor Kasap hakkında kaleme aldıklarına karşı bir cevap metni özelliği taşıyan yazıda Kahkaha ve Basiretci Ali Efendi'den de bahsedilmesi Hayal tarafından Kara Sinan ile Kahkaha arasında bir işbirliğinin varlığına inandığını göstermektedir. Başka bir ifade ile Teodor Kasap'a göre Karidi “düşmanımın düşmanı dostumdur” ilkesi ile hareket etmektedir. Üslup açısından Hayal dergisi ve Teodor Kasap'ın Kara Sinan ile yaşanan polemiğe son verme niyetinde olduğu yazının son kısmından anlaşılmaktadır. Ancak İzmir'den gelen bir mektup Kara Sinan ve Karidi'yi tekrar Hayal dergisinin gündemine oturtur: 


\section{İzzetlü efendim}

Müddet-i vefireden beri bab-1 mükâtebenin küşadına arzu-keş ettiysem de kesret-i meguliyet acizanemden bir münasib vakit bulamadım işte şimdi İzmirde hakk-1 aleyinizde olmak üzere neşr olunan evrek şu mektubun takdimine bendelerini mecbur ediyor. Kara Sinanın dördüncü nüsha-i melanetindeki rezil bendin yalnız Gir Karidis tarafından tahrir olunduğuna zâhib olmayasınız vakıa sizin geçen hafta tab' ü neşr buyurmuş olduğunuz benden merkum gir karidis pek me'yus kalmış ise de asıl böyle edebsizce bend yazanlar tercüme odasında yani hükümet konağında Mesut Fikri Efendi ve meclis temyiz müstantiklerinden olup bundan akdem devletlü Ahmet Rasim Paşa hazretleri zamanında çıkarılmış iken sonra her nasılsa alınmış olan Hasan Bey ve ale'l-husûs Karaburun nahiyesi müdürü esbak Mehmet Efendidirler. Bu Mehmet Emin Efendi denilen şahıs birkaç defa memuriyetlerinden çıkarılmış bir adamdır. Şimdi ise hükümet kapısında avukatlık ediyor. Merkum Hasan Bey gibi bu dahi hamamcı esnafından diyorlar. Karidis böyle adamlarla düşüp kalkıp bunlardan muavenet bekliyor. Hele kendisi Alaşehir şimendiferinin resm-i küşadı icra olunduğu gün Alaşehir istasyonunda o kadar keyf olmuş ki (zira şarabı bedhava bulmuş) iki adamla vagona koyup İzmire öyle gelmiştir. Vay gidi papazlık vay. Vay gidi gazetecilik vay. Hele Basiret sahibi izzetlü efendi hakkında açıktan açığa (cahil merkep) yazmalarına ne demeli ha unutmayalım ıslahhaneyi fare kapanına teşbih ettirip üzerine ay ve yıldan nişan-1 şecâat unvanı koymasına ne dersiniz.

Şimdilik bu kadar. Haftaya pek çok yazacak şeyler var.

$$
\text { Hayal }
$$

İsimleri bâlâda zikr olunan zevat-1 nezdlerinde mahiyeti malum olmak lazım gelen bir papaza muavenet maksadıyla tanımadıkları bir adam aleyhinde bir takım herze-gûllukta bulunmuşlar ise bu mektubu yazan zatın mektubunda beyan ettiği hususatta hakkı vardır çünkü yazanlar hakikaten bunlar ise evsaf-ı mezkûre harcında bulunamayacakları derkârdır. (Hayal, 6 Temmuz 1875: 3)

Gönderen kişinin ismi ya da imzasının bulunmadığı bu mektup, Kara Sinan dergisinin 4. sayısında Teodor Kasap hakkında yazılanların Karidi tarafından değil de Mesut Fikri Efendi ve Mehmet Emin Efendi tarafından yazıldığını iddia etmektedir. Bu iki isimden Mehmet Emin Efendi'nin derginin başyazarı olarak tanımlanan Emin Efendi (Huyugüzel, 1996: 54) olması muhtemeldir. Ancak Mesut Fikri Efendi ve Hasan Bey hakkında ise literatürde bir bilgi bulunmamaktadır. Hayal dergisinin mektuba tepkisi 164. sayısında Karidi'ye karşı takındığı tavır ile aynıdır. Polemiği uzatmak istemeyen Teodor Kasap'a göre kendisini tanımayan ve kendisinin de tanımadığı bu şahısların gazetecilik anlamında gerekli donanıma sahip olmamaları ortaya konulan saçmalığın sebebidir.

165. sayısında yer alan mektuba verdiği cevap ile Hayal dergisi, İzmir ve Kara Sinan defterini kapatmıştır. Ancak Kara Sinan İstanbul basınına mızrağını uzatmaya 6. sayısında da devam etmiştir:

Malum âlî-i sinanileri buyurulduğu üzere bizim çıkarmakta olduğumuz gazeteler gazete denilmeye şayan olmayıp adeta keşkül fikra ve daha açık tabirle mekanın cennet ola pus[u]lası demek olduğunu inkar edemeyiz bununla beraber şu vazifeyide layıkıyla icra edemeyerek içimizden kimisi müdâhenenin pek ziyade haricine çıkıyor ve kimimiz imlasız manasız bendler ile halkın teşviş-i ezhanını mucib oluyor ve bazılarımız dahi tulumbacı ıstılahıyla içimizden bazılarına sövüp sayıyor ve bir takımımız dahi gazete çıkar çıkmaz gayet ehven fiyata okka hesabıyla bakkallara satıyor hasılı yalan bizde müdâhene bizde zevzeklik bizde kă̆ıtçı merkebi dolandırmak bizde bedhava muharrir mütercim mürettib kullanmak bizde...

Hülasa bizde oğlu bizde e ya bizim böyle halimiz ne olacak lütfen merhamet-i tarafınızdan buraya bir vekil mi gönderip bize tâyin-i vazife buyurursunuz yoksa kullarınızı mı huzur-u devletinize celb ile bir divan mı verirsiniz ne yapar iseniz yapınız bizim 1slah-1 halimize himmet buyurunuz zira işimiz duman halimiz yamandır yine her halde emr ü ferman hazret sinanilerinindir Sadakat Vakit Hayal Basiret Ceride-i Havadis Köriye Deoriyan Bizantis La Turki Mikra Asia yani Anatoli Fordu Bosfor bilcümle ermeni gazeteleri Letâif-i Âsar Meddah 


\section{Kara Sinan}

Alındı bir defa şimdi buna ne demeli sükut etsem olmaz söylesem işime el vermez a gözüm beni gazetelerin 1slahına memur-1 mahsus zan ettiniz? Bendeniz burada bulunan gazetecileri terbiyeden acizim cenab-1 hak matbuat nizamnamesinin nazar-1 kem-yab eserini gazetelerin üzerinden eksik etmesin benim ne haddim gazetecileri terbiye etmek... acizlerinin ki bir nasihat idi onu da dinleyen dinledi dinlemeyen yine eski halinde kaldı bizim bura gazetecilerinde istidat yok zekâvet yok ne yapmalı bilemem bunlara nasihatimi tesir ettirecek olur isem ba'de İstanbul gazetelerinin dahi çaresini düşüneceğimi ve bu ihtiyar halimde değneğimi kakaraktan şimdilik İstanbula kadar gelemeyeceğimi ma'al-itizar ve el-teessüf beyan ederim epeyce uydurabildim mi evet acaba İstanbul katipleri bana gülerler mi evet öyle ise bende onlara şimdiden güleyim kah kah kah hah hah hay (Kara Sinan, 8 Temmuz 1875: 3-4)

Kara Sinan gerek ilk sayısında gerekse de 3. sayısında İstanbul basını içerisinde sadece mizah basınını odak noktası olarak almakta iken bu yazı ile İstanbul'da yayımlanan Türkçe ve Türkçe dışı bütün süreli yayınları hedef almaktadır. İstanbul basınının tamamını dalkavukluk, zevzeklik ve yalancılık gibi vasıflarla tanımlayan dergi, İstanbul'a karşı bir meydan okuma ortaya koymasının yanı sıra cepheyi de oldukça geniş tutmaktadır. Her ne kadar bütün İstanbul basınını karşısına almış görünse de Kara Sinan'ın doğrudan hedefinde olan isim Teodor Kasap'tır. Hayal'in 165. sayısında yayımlanan yazıya Karidi tekrar bir muhavere ile cevap verir:

- Sinan Beyefendi.. Bu hafta gelen Hayal gazetesini gördünüz mü

- Hayali ne yapmalı İstikbali beklerdim.

- Hayalin İstikbali olur mu

- Olmasa olmazd1

- Ben size Hayali söylüyorum Hayali

- Hayale ne olmuş ne var Hayalde

- Ne olacak senin dostların İzmirden mektup yazmışlar.. Size muharrirlik ediyor diye bir takım zatın aleyhinde ağızlarına geleni söylemişler.. Ve daha söyleyeceklermiş.

- Öyle ise onlar benim dostlarım olmamalı.. Karagözün dostları ve belki akrabalarıdır! Zira yine hemcinsi çeker birbirinin gayretini derler. Mutlaka bunlar Karagözün akrabalarıdır.

- İzmirde Karagözün akrabaları olduğunu hiç işitmemiş idim.

- İşitmedin mi.. Dağ mahallesindeki ayarı bozuk Mıstıkla Palavra sulu şeftali çekirdeği Hüsnü Karagözün taallukatından değiller mi

- Ya öyle mi... Ha şöyle.. Ben de İzmirden bu mektubu kim yazmış diye merak ediyordum.

- Bunda merak edecek ne var? Geniş olmalı geniş̧.

- Demek ki siz aldırmiyorsunuz.

- Hayır biz alay geçiriyoruz.

- Öyle ise aşk olsun.

- Aşk olsun ya!..sen ne zannettin.. Ben öyle patırtıya papuç mu bırakırım.. hey kuzum hey darıdan korkan hiç serçe eker mi.. Bir takım şev suratlar kalkmışlar da.. Filan efendi filan bey Kara Sinana muharrirlik ediyorlarmış şöyle imiş böyle imiş.. ben zaten kalabalıktan hoşlanmam.. Benim dairemi bir katip de idare ediyor.. Ben Kasapoğlu gibi akılsız mıyım. Başıma bir takım haşeratı toplayım da alemi mizaha aldırayım?. Eğlenecek olsam kendim eğlenirim.

- Vay Kasapoğlunun muharrirliğe iktidarı yok mu 
- Ne dedin ne.. İktidar mı iktidar mı.. Onu ben kendim de bile göremiyorum.. Kasapoğlununki boyacılıktan ibarettir.. Adeta garsonluğundan hizmet ettiği mösyöden bir iki Fransızca lügat çarpmış işini beceriyor.. Bizim sade suya beylere (mersi) (pardon) (ben ne ne ne sivilazsiyon) (uydurmasyon) dedikten sonra sinekten ziyade Kasabın dükkanına tecemmü’ eder ve kendilerine gazete muharriri densin diye akıllarına her ne gelirse yazarlar.

- Bunların işi gücü yok mu.. Bu beyler kimlerdir.

- Kim olacak mazi bey muzari’ bey masdar bey fail bey ... istikbal bey hal bey velhasil kendilerine olur olmaz memuriyeti yakıştıramayan ne kadar kaldırım mültezimi var ise Hayale devam eden bunlardır bunlara iş güç olmaz bu zatlara mirasyedi derler anladınız mı

- Anladım.. Anladım

- Anladınsa da anlamadınızsa da tekrar ifadeye vaktim yoktur. Şimdilik uğurlar olsun. (Kara

Sinan, 15 Temmuz 1875: 1-2)

İzmir'den gönderilen ve Hayal dergisinde yayımlanan mektupta Teodor Kasap hakkında "adaba mugayir" ifadeleri Karidi'nin yazmadığı ve bu durum için üzgün olduğu belirtilmiştir ancak yayımladığı bu muhavere ile Karidi iddiaları ret etmektedir. Ayrıca mektupta ismi geçen MesutFikri Efendi, Hasan Bey veMehmetEmin Efendiile de birilişkisi olmadığını belirtmektedir. Bununla birlikte Teodor Kasap hakkında yeni bir tanımlama olarak "muharrirliğe iktidarı yok" cümlesini sarf eder. Bu ifadeyi Kasap'ın gazetecilik mesleğinin gerektirdiği yeterliliğe sahip olmaması şeklinde yorumlamak mümkün ki burada Karidi'nin kast ettiği Teodor Kasap'ın Türkçe konuşmasına karşın yazamaması ve yazılarına yeğeni Lazaridis'in yardımcı olduğudur (Kut, 2011: 474). Karidi'ye göre Kasap “garsonluk hizmetinde bulunduğu mösyö” yani Alexandre Dumas'dan öğrendiği Fransızca ile Türkçe yazamama yetersizliğini gizlemeye çalışmaktadır. Kara Sinan'ın bu "iğneleme"lerine Hayal dergisi karşılık vermemiştir ancak Kara Sinan mızrağını tekrar Hayal'e doğru uzatır fakat bu kez kullandığı silah karikatürdür.

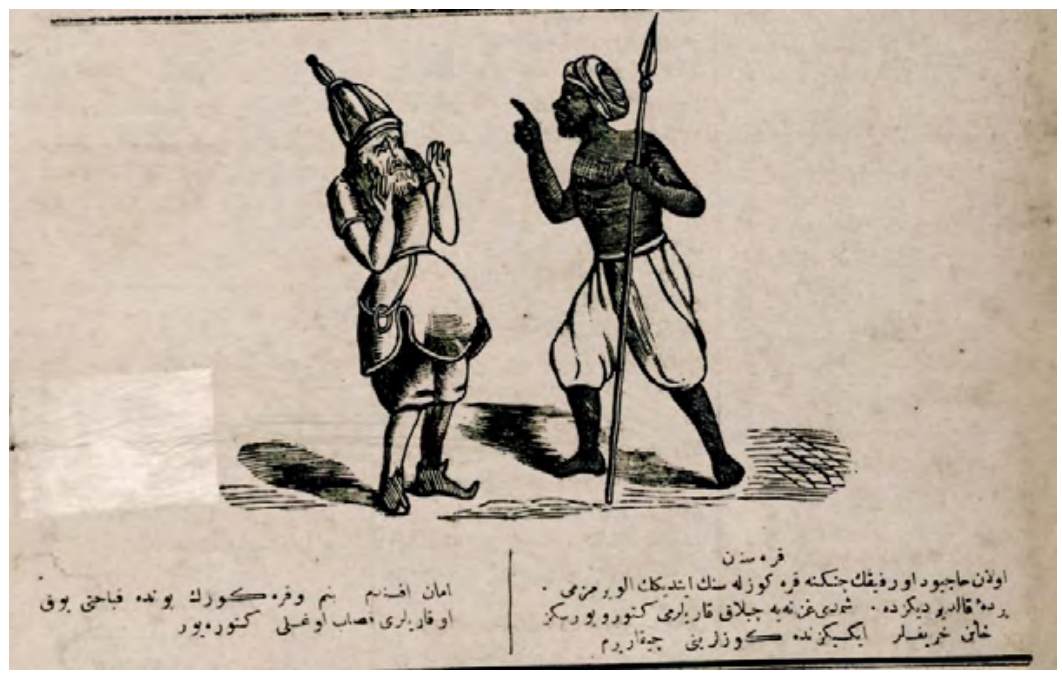

Görsel 4: Kara Sinan, Sayı: 10, 5 Ağustos 1875.

Karikatürde elinde mızrağı ile Kara Sinan karşısındaki Hacivad'ı azarlamaktadır: "Ulan Hacivad o refikin çingene Karagözle senin ettiğin el vermez mi. Perdeyi kaldırdınız da şimdi gazeteye çıplak karıları mı getiriyorsunuz hain herifler ikinizin de gözlerini çıkarırım”. Elleri havada korkmuş bir ifade ile Hacivad: “Aman efendim benim 
ve Karagözün bunda kabahati yok o karıları Kasapoğlu getiriyor" cevabını vermektedir (Bkz. Görsel 4). Kara Sinan'ın "gazeteye çıplak kadın getirme” şeklinde bahsettiği olay büyük ihtimalle Hayal'in 176. sayısında yer alan karikatürdür (Bkz. Görsel 5).

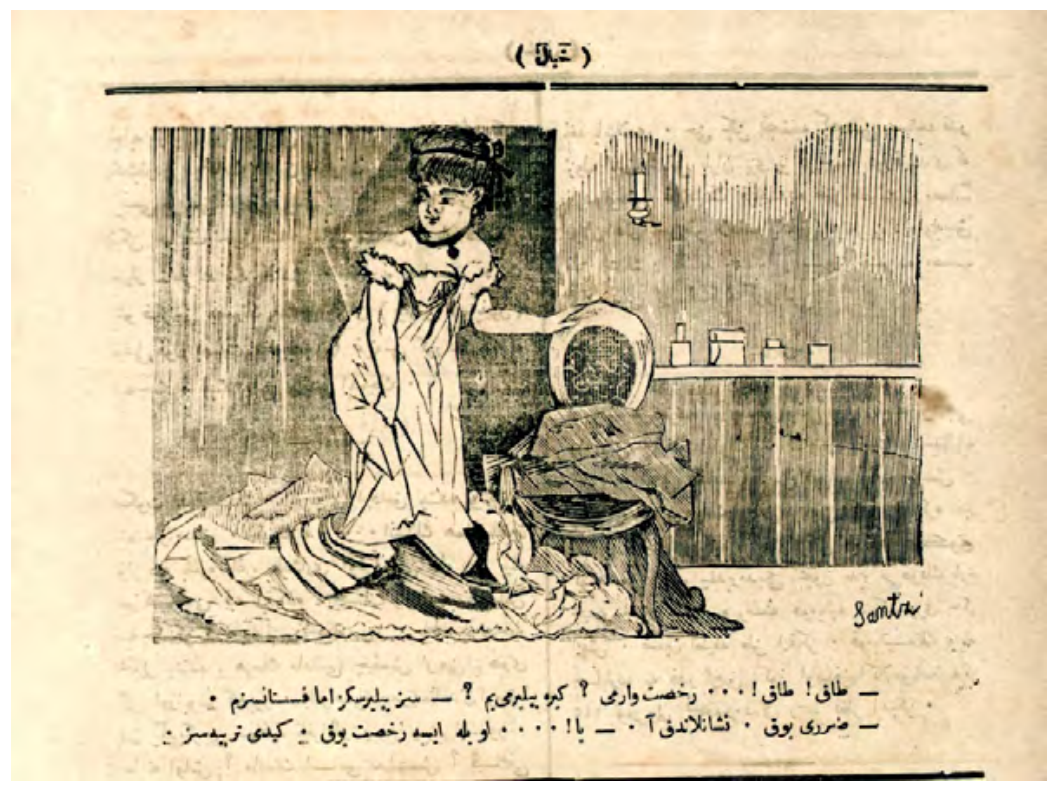

Görsel 5: Hayal, Sayı: 176, 31 Temmuz 1875.

Santri imzalı karikatürde soyunan bir kadın görülmektedir. Lejand ise şu şekildedir:

- Tak! Tak!...ruhsat var mı? Girebilir miyim?

- Siz bilirsiniz ama fistansızım

- Zararı yok nişanlandık a.

- Ya!.... Öyle ise ruhsat yok. Gidi terbiyesiz.

Hayal, bu karikatürünü “ahlaksızlık” olarak tanımlayan Kara Sinan’a bir karşılık vermemiştir. Kara Sinan'ın sataşmaları karşısında Teodor Kasap'ın suskun kalışını "İzmir dosyasını kapatmak" şeklinde yorumlamak mümkündür. Bununla birlikte Teodor Kasap'1n suskunluğunda 14 Ağustos 1875 tarihinde Hayal dergisini Misialidis'e devrederek 22 Ağustos 1875 tarihinde günlük İstikbal gazetesini yayımlamaya başlaması da etkili olmuştur.

İstanbul dışında Tanzimat dönemi mizahının temsilcisi olan Kara Sinan'ın Hayal ile arasındaki ilişkinin bir nevi husumet üzerine kurgulandığı ve bu kurgu içerisinde tarafların birbirleri hakkında kalemlerine sınır koymadıkları gözlemlenmektedir. Bu durum, Kara Sinan'ın "reklam stratejisi” olarak düşünülebileceği gibi yerel bir rekabetin de sonucu olması ihtimal dahilindedir. Karidi'nin İzmir basını içerisinde "kanlı bıçaklı" olduğu Mehmet Salim, Kara Sinan yayımlandığı dönemde İntibah gazetesinin başyazarıdır. Kara Sinan'ın mevcut nüshaları incelendiğinde Karidi ile Mehmet Salim arasında bir kan davası bulunduğu görülmektedir. Bununla birlikte İntibah gazetesinin imtiyaz sahibi olan 
Corci Bubli'nin Namık Kemal ile yakın arkadaşlığı ${ }^{7}$ İstanbul-İzmir ekseninde İntibah gazetesi ile Hayal dergisi arasında da olumlu ilişkilerin var olabileceği sonucunu akla getirmektedir. Corci Bubli'nin gazetesi İntibah'ın yaşadığı matbaa ve hurufat sorununu Hayal' in eski hurufatını satın alarak çözüme kavuşturmuş olması (Demirkol, 2021: 230) en azından bu iki isim arasında bir ticari ilişkinin varlığını somut olarak ortaya koymaktadır. Bu ilişki Karidi tarafından Teodor Kasap'ın rakipleri Corci Bubli ve Mehmet Salim'in yanında yer aldığı şeklinde yorumlanarak Hayal dergisini kendisine hedef olarak seçmiş olma ihtimalini olasılıklı hale getirmektedir.

Kara Sinan ve Karidi ile ilişskili İstanbul mizah basınında yazı kaleme alan bir diğer dergi ise Geveze'dir. Mehmet Tevfik'in Letâif-i Âsar dergisinden sonra yayımladığ 1 Geveze, Aydın gazetesinde yer alan bir ilanı sayfalarına taşıyarak dolaylı da olsa Kara Sinan dergisinden bahseder:

Aydın gazetesinin ekser nüshalarını nazar-ı mütalaadan geçiriyoruz geçiriyoruz da ne görüyoruz hiç. Fakat yalnız her nüshasında bir vech-i zir derc olunan şu ilanı görüyoruz. Bundan da bir şey anlayamiyoruz. Anlayan varsa aşk olsun.

İzmirde frank mahallesinde Baltacı Frankhanesinde kâin İzmirni ve Velos ve Kara Sinan gazetelerinin matbaasında Türkçe ve Fransızca ve Rumca cedid ve ila hurufat mevcud olduğu gibi kemal-i nefaset üzere yapılmak için mahir usta ve makineleri olduğundan te'lifata dair her bir iş ve duhân etiketi ve ilanat ve her nevi matbu evrak yüzde yirmi tenzil-i fiyatla kabul olunur. (Geveze, 6 Ağustos 1875: 4)

Aydın gazetesinde hem Türkçe hem de Rumca yayımlanan bu ilanda Geveze'nin neyi eleştirdiği anlaşılamamaktadır. Ancak 15 Temmuz 1875 tarihli Aydın gazetesinde yer alan metinde bir kelimenin değiştirildiği görülmektedir. Metnin son kısmında yer alan "duhân etiketi" ibaresi "duhân bandrolleri" şeklinde düzeltilmiştir. Baskida yapılan kelime hatasını dile getiren Geveze dergisi 2. sayısında ise doğrudan Kara Sinan'1 hedef almıştır:

Şaraptan bozma sirke gibi papazlıktan çıkıp gazeteci olma birisi İzmirde Kara Sinan namında bir eğlence gazetesi çıkarıyormuş. Birkaç tanesi ezcümle dokuz numaralı nüshası nazar-1 mütalaadan geçirildi. Şive-i kitabetle fikrine diyecek yoksa da imlasına hiç diyeceğimiz yoktur. Çünkü bilmediğimiz yolda bir imla nasıl imla diye merak edecek olursanız işte bir tanesini gözünüze göstereyim de bakınız ama siz diyeceksiniz ki evet mürettip hatasıdır. Hayır böyle mürettip hatası olmaz bu mutlak yeni çıkma bir imla olmal1.

Mezkur numaralı nüshada (başımıza bir de ferdi bosför çıktı) unvanıyla yaşmış olduğu makalenin nihayetinde (eğer ferdu fosför bunların bir daha gelmemelerini arzu eder ise de) demiş gördünüz mü. Biz bu arzunun arzu olduğunu bilirdik ama (arzu) olduğunu siz bilir miydiniz? Hayır? Anladınız mı şimdi efendim herif alem şey alem elbette papaz kısmı alem olur böyle olmazsa ayıp olur. (Geveze, 10 Ağustos 1875: 3)

Kara Sinan dergisinin 9. sayısında Phare du Bosphore gazetesinin İzmir ile ilgili yayımladığı habere karşılık kaleme alınan yazının son kısmında "eğer ferdu fosför bunların bir daha gelmemelerini arzu eder ise" şeklinde bir ifade yer almaktadır. Bu ifade içerisinde "arzu" kelimesi dergi tarafından yanlış yazılmıştır. Doğru imla ile arzu kelimesi [وضرا'] şeklinde yazılırken Kara Sinan "dad” harfini kullanarak arzu kelimesini şeklinde yazmıştır. Derginin yapmış olduğu bu imla hatası Geveze'ye göre Karidi'nin mesleki yetersizliğinin bir işaretidir. Karidi ise Geveze'nin yazdıklarına 12. sayısında kars1lik verir:

7 Namık Kemal, Midilli’den İzmir’e geldiğinde Corci Bubli onu evinde misafir etmiştir (Bkz. Huyugüzel, 2000: 125). 
Şu Karagöz münasebetsizdir ama bazı vakitte söylediği çıkıyor. Geçenler de Letâif-i Âsârın ismini tebdil edeceklerine sahib-i imtiyazı ismini tebdil etse daha güzel olur demiş idi. Dediği gibi çıktı ve Tevfik imzası üzerine bir de papadopoli ilave edildiği görüldü.

Bizim meçhulümüz ise de bu Papadopoli Tafik Ağa imladan da anlar imiş.

Bu papadopoli Tafik Efendi gayet müdekkik olduğundan gazetelerin imlaca kusurunu tutar imiş.

Bu papadopoli mösyö Tafik gevezelikte kendine emsal arar imiş.

Bu papadopoli senyor Tafik hayal gibi masharalık edebiliyor da beş on kuruş çarpabiliyor muyum diye Karapanos Efendi hakkında baldırı paçayı sığar imiş.

Bu papadopoli kirlos Tafik umum millete kendisi gibi miskinlik isnad imiş.

Bu papadopoli efkârı bozuk Tafik millet-i İslamiyyede ismini zikredecek fazıl bir zat bulamamış da mektep çocuklarının Volter gibi hiçbir dinde alakası olmayan bir herife nisbet eylemiştir.

Ha burası da hatıra gelir böyle gevezeliği hep Papadopoli Tafik ağa yazamaz ya.

Herifin bir çok katipleri varmış. Onlar birbirini dürte dürte teşvik ede ede düşüne düşüne böyle gevezelikler çıkarırlar imiş.

Güleyim şunların gevezeliklerine de hayalığına da...

Yazık onların şaklabanlığına da soytarılı̆ıına da. (Kara Sinan, 20 Ağustos 1875: 1)

Kara Sinan, Geveze dergisinin kendisine ilişkin imla hatası üzerinden ortaya koyduğu eleştiriye bir baskı hatası ile karşı1ık vermiştir. Geveze'nin 2. sayısında "ajans Papadopoli tarafından havadis-i şifahiyye" başlıklı, İstanbul ve yurtdışından haberlerin mizahi bir dille kaleme alındığı metnin altında yer alan "imza Papadopoli” ibaresi derginin imtiyaz sahibi Mehmet Tevfik' in isminin hemen üstüne denk gelmiş (Bkz. Görsel 6) ve bu durum Kara Sinan tarafindan "Papadopoli" ve "Tevfik" ibarelerinin "Papadopoli Tevfik" şeklinde tek isim olarak okunarak eleştirilmesine sebep olmuştur. Kara Sinan aynı sayısında Geveze ile ilgili ikinci bir yazı daha kaleme almıştır:

Papadopoli Tevfik isminde bu hafta matbaamıza bir geveze geldi. Amma ne geveze. Gevezenin gevezesi denmeye şayan ve gayetle şaklaban olup herifte hiç sıkılma yok. Münasebetli münasebetsiz ağzına ne gelirse veryansın gidiyor. Canım geveze de lazım amma böylesi değil azıcık da sözü sohbeti dinlenmeli. Bu köftehor Fransızların verdikleri beş milyar tazminata pişman olduklarını bilmem nesini lakırdı kıtlığında söylüyor. Aralıkta da ıstılah paralayacağım diye ezilip büzülüp (zihi hayal batıl zihi efkâr muhal) gibi küflenmiş şeyleri tazeliyor. Artık ne diyelim Cenab-1 Hak İstanbul ahalisine sabırlar ihsan etsin. Bunu dinleyenler kulaklarına pamuk tıkamalıdır. (Çünkü gevezenin anasını sağırlık bellermiş.) ben de onun için sağırlığa vurdum. Doğrusu öyle soğuk gevezeler dinleyemem dinleyen varsa o da gevezedir. (Kara Sinan, 20 Ağustos 1875: 3)

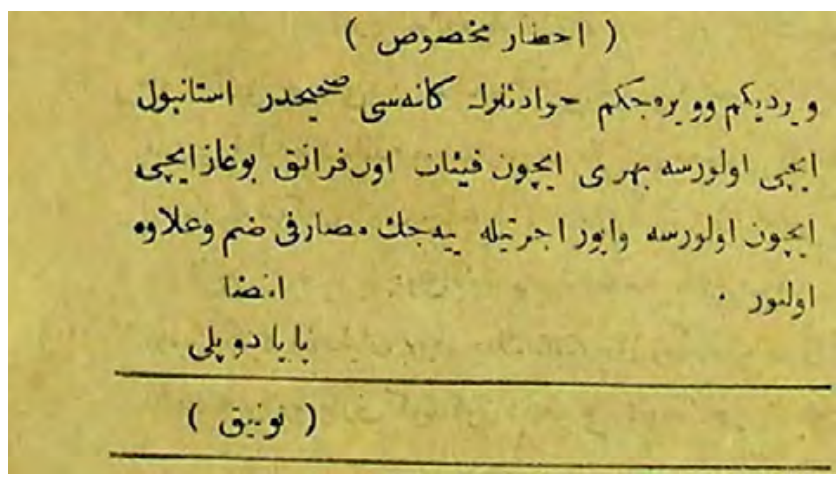

Görsel 6: Geveze, Sayı: 2, 10 Ağustos 1875. 
Bu yazı ile Kara Sinan, Geveze'nin içeriğine odaklanır. Temel eleştiri içeriğin yetersiz oluşu ve hazırlanırken özensiz davranılmasıdır. Bu eleştirisini de Geveze'de yer alan “ Bundan evvel vuku' bulan Fransa ve Prusya muharebesinde Fransizların gayb ettikleri ve beş milyar tazminat verdikleri cihetle anlaşıldığına göre Fransızlar bu muharebeden pek de memnun olmamışlardır" (Geveze, 10 Ağustos 1875: 4) cümlesi üzerinden ortaya koymaktadır. 1870-1871 y1llarında gerçekleşen Fransa-Prusya savaş1 hakkında dört yıl sonra bu şekilde bir içerik üretilmesini "özensizlik" göstergesi kabul etmenin yanı sıra Kara Sinan, Geveze dergisinin durumunu boş hayallere kapılarak imkânsız şeyleri düşünen anlamındaki "zehi hayal-i bâtıl zehi efkâr-1 muhal"» atasözü ile tanımlar. Karidi ve Kara Sinan dergisinin İstanbul mizah basını ile ilişki ağı içerisinde nispeten olumlu ilişkilere sahip olduğu Mehmet Tevfik ile aralarında yaşanan bu atışmaları iyi ilişkilerin sekteye uğraması şeklinde yorumlamak yanlış bir eğilimdir. Tanzimat dönemi mizah basını içerisinde dergilerin birbirlerinin imla hatalarını bulması, içeriğin yetersizliği ile mesleki ehliyetin bulunmaması polemik geleneğinin temel unsurlarıdır. $\mathrm{Bu}$ açıdan Geveze-Kara Sinan atışmalarını dönemin gazetecilik pratikleri ile uyumlu ve olağan üslup çerçevesinde tanımlamak mümkündür. Bununla birlikte Mehmet Tevfik ile Karidi arasındaki iyi ilişkilerin bir göstergesi de Mehmet Tevfik'in Çaylak dergisinde Kara Sinan dergisinden "İzmirde bizim kara oğlan (yani Kara Sinan) tarafından aldığımız telgraf (...)" (Çaylak, 12 Mart 1876: 4) şeklinde bahsetmesidir. Bu durum İstanbul-İzmir hattında Karidi-Mehmet Tevfik arasında iyi ilişkilerin devam ettiğini göstermektedir.

İstanbul mizah basını içerisinde Kara Sinan dergisine sayfalarında yer veren bir diğer dergi ise Tiyatro'dur. Hagop Baronyan dergisinde telgraf formunda "Kara sinanın yüzünü kara çıkarmamak üzere olunan say' ve gayrete nispetle kara sinanın yüzü gün be gün kararmaktadır" (Tiyatro, 8 Eylül 1875: 3) şeklinde bir metin yayımlar. Bu metni Tiyatro'nun 10. sayısındaki "kara sinan karaciğer hastalığından kesb-i ikamet edemeyerek kara toprağa girmeye mecbur oldu" (Tiyatro, 15 Eylül 1875: 4) cümlesi takip eder. Tiyatro, "kara toprağa girme" ifadesi ile Kara Sinan'ın 10 Eylül 1875 tarihli 15. sayısından sonra aldığ 3 ay kapatma cezasından bahsetmektedir. Dönemin mizah dergileri mali açıdan büyük oranda tiraj ve reklam gelirlerine bağımlı oldukları için 3 ay gibi uzun bir süre kapatılmak bir yayıncı için ölümle eşdeğer bir durumdur. Tiyatro dergisinin Kara Sinan'ın "kara" bahtını sayfalarına taşıması bu anlamda bir mesleki dayanışma veya nezaket ile açıklanabilir.

\section{Sonuç}

19. yüzyılda Türkçe basının merkezi olan İstanbul aynı zamanda 1870 yılında yayımlanmaya başlayan Türkçe mizah dergilerinin de okuyucu ile buluştuğu şehirdir. 1875 yılında İzmir'de Karidi tarafından yayımlanan Kara Sinan dergisi ile Türkçe mizah dergileri "taşra"ya da taşınmıştır. İzmir'de bir Türkçe mizah dergisinin yayımlanması karşısında İstanbul mizah basını içerisinde bu gelişmeyi olumlu karşılayan isimler ise Mehmet Tevfik ve Basiretci Ali Efendi'dir. Mehmet Tevfik dergisi Letâif-i Âsar'da ve Ali Efendi de gazetesi Basiret'te Kara Sinan dergisinin yayımlandığını okuyucuları ile paylaşarak "taşra"ya taşınmış Türkçe mizah dergiciliğine olumlu yaklaştıklarını göstermişlerdir. Mehmet Tevfik ve Basiretci Ali Efendi’nin aksine Kara Sinan’ın

8 Bu ifadenin sık kullanılan şekli; “zehi tasavvur-1 bâtıl zehi hayal-i muhal”dir (bkz. Peran, 2019: 89). 
yayımlanması karşısında olumsuz tavır takınan tek isim ise Teodor Kasap'tır. Dönemin en önemli Türkçe mizah dergisi olan Hayal dergisi, Kara Sinan'ın yayın hayatına başlamasını daha çok yayıncısı Karidi üzerinden eleştiren bir tutum sergilemiştir. Hayal dergisinin olumsuz tavrının odağında "mesleki yetersizlik" olgusu yer almaktadır. Karidi tarafından Kara Sinan'dan önce yayımlanan Rumca Velos dergisi üzerinden eleştirilerini ortaya koyan Hayal dergisi Velos'u "başarısız" bir dergi ve Karidi'yi de "yetersiz" bir yayıncı olarak tanımlar. Bu açıdan Kara Sinan da önemsiz bir girişimdir. Genel olarak Teodor Kasap'ın ortaya koyduğu olumsuz tavrın sebebinin, tematik bir yayın olarak Türkçe mizah dergilerinin kısa bir geçmişe sahip olduğu 1875 yılında İstanbul dışında bir şehirde yeni bir Türkçe mizah dergisinin yayın hayatına başlamış olmasından çok bu girişimin altında Karidi isminin yer alması olduğu söylenebilir. Bu durum Teodor Kasap ile Karidi arasında geçmişe dayanan bir ilişkinin varlığını ya da birbirlerinin “özgeçmiş”lerini yazacak kadar tanışıklıklarının bulunduğu sonucu ortaya çıkarmaktadır.

İzmir'de Kara Sinan'ın yayın hayatına başlamış olmasını Mehmet Tevfik ve Basiretci Ali Efendi olumlu karşıladıklarını net bir biçimde ortaya koyarken Teodor Kasap ise Karidi imzalı bu girişimin uzun ömürlü olmayacağını düşünmektedir. Bu isimlerin dışında kalan Tiyatro, Meddah ve Latife dergileri ise Kara Sinan'ın yayımlanmasına karşı sessiz kalmışlardır.

İstanbul-İzmir hattında Kara Sinan dergisinin İstanbul basını karşısındaki konumlanışını ise "varlığı ile korku salan zorlu bir rakip" şeklinde tanımlamak mümkündür. Ancak bu tanımlama Kara Sinan'ın kendisine aittir. Özellikle 3. ve 6. sayılarında yer alan yazılar bu tanımlamanın temelini oluşturmaktadır. Karidi'nin bu şekilde bir tanımlama üzerinden dergisini konumlandırmasının iki sebebi olduğu varsayılabilir. Öncelikle polemikçi bir üslup ile söyleme dökülen bu tanımlama derginin satış rakamlarını artıcı bir unsurdur. Dönem basını incelendiğinde okuyucunun ilgisini çeken ana konuların başında süreli yayınların birbirleri ile yaşadıkları kalem kavgaları geldiği görülmektedir. Böyle bir durumun İstanbul ve İzmir gibi iki farklı şehirde yaşanmış olması da okuyucunun ilgisini cezp edici bir durum olarak yorumlanabilir. İkinci etken ise Karidi'nin dergisi Kara Sinan'1 İzmir'in yanı sıra mizah yayıncılığı piyasasının merkezi olan İstanbul'da da var etme gayretidir. Bunu destekleyen olgu ise İstanbul'un önemli günlük gazetesi olan Basiret'te Kara Sinan reklamlarının yer almasıdır. Basiret'te yer alan reklamlara karşın Kara Sinan'ın coğrafik anlamda temel okuyucu kitlesine ulaşan Aydın gazetesinde dergiden ziyade derginin basıldığı İzmirni Matbaası'nın reklamlarının yer alması da bu durumu desteklemektedir. Kara Sinan'ın Basiret'te yayımlanan reklamları aynı zamanda iki şehrin basını arasında ticari ilişkilerin de varlığını göz önüne sermektedir.

İstanbul'da Türkçe mizah dergisi yayıncılığının gelişiminde Ermenice ve Rumca mizah dergisi yayıncılarının önemli katkısı bulunmaktadır. Aynı durumun İzmir için de geçerli olduğu görülmektedir. İzmir'in ilk Türkçe mizah dergisi olan Kara Sinan, Rumca bir mizah dergisi yayıncısı olan Karidi'nin imtiyazı ile yayın hayatına başlamıştır.

Kara Sinan dergisi İzmir'in ilk Türkçe mizah dergisi olmasının yanı sıra 18701877 yılları arasında basının merkezi olan İstanbul dışında yayımlanmış ilk mizah dergisi olmakla birlikte "mizah dergisi" olgusunu "taşra"ya da taşıyan bir yayındır. Tanzimat dönemi mizahına yeni bir soluk getiren Kara Sinan, İzmir’i Tanzimat mizahının ikinci şehri haline getirmiştir. 


\section{Kaynaklar}

And, Metin, (1977). Gölge Oyunu, Ankara: Türkiye İş Bankası Kültür Yayınları.

Arıkan, Zeki, (1985). "Tanzimat ve Meşrutiyet Dönemlerinde İzmir Basını”, Tanzimat'tan Cumhuriyet'e Türkiye Ansiklopedisi Cilt 1, İstanbul: İletişim Yayınları, s.103-111.

“Ayvansaraydan tahrirat”, Çaylak, Sayı: 12, 12 Mart 1876 (15 Safer 1293 / 28 Şubat 1292), s.4.

Bardakjian, Kevork, B., (2017). Sivri Dilli Dâhi: Hagop Baronyan'ın Siyasi ve Toplumsal Hicvi, Fırat Güllü, Zeynep Okan (çev.), İstanbul: bgst Yayınları.

Basiret, Sayı: 1545, 8 Haziran 1875 (4 Cemaziyelevvel 1292 / 27 Mayıs 1291), s.1.

Basiret, Sayı: 1706, 12 Ocak 1876 (15 Zilhicce 1292 / 31 Kanunievvel 1291), s.4.

“Bir papaz gazeteci”, Hayal, Sayı: 156, 15 Haziran 1875 (3 Haziran 1291), s. 2-3.

Çeviker, Turgut, (1986). Gelişim Sürecinde Türk Karikatürü Cilt 1, İstanbul: Adam Yayınları.

Demirkol, Gökhan, (2016). “Türkiye'nin İlk Türkçe Mizah Dergisi: Terakki”, Gazi Akademik Bakış, 10(19), s.141-160.

Demirkol, Gökhan, (2021). “İzmir'de İkame Bir Türkçe Mizah Dergisi: İlâve-i İntibah (1875)", Üsküdar Üniversitesi Sosyal Bilimler Dergisi, 12, s.205-235.

Geveze, Say1: 1, 6 Ağustos 1875 (4 Recep1292 / 24 Temmuz 1291), s.4.

Geveze, Say1: 2, 10 Ağustos 1875 (8 Recep 1292 / 28 Temmuz 1291) s.3.

Hayal, Sayı: 1, 30 Ekim 1873 (18 Teşrinievvel 1289), s.1.

Hayal, Say1: 164, 3 Temmuz 1875 (21 Haziran 1291), s. 2-3.

Huyugüzel, Faruk, (1996). 1928'e Kadar İzmir'de Çıkmış Türkçe Kitap ve Süreli Yayınlar Kataloğu, İzmir: Ege Üniversitesi Edebiyat Fakültesi Yayınları.

Huyugüzel, Faruk, (2000). İzmir Fikir ve Sanat Adamları (1850-1950), Ankara: Kültür Bakanlığı Yayınları.

İnuğur, M. Nuri, (2005). Basın ve Yayın Tarihi, İstanbul: Der Yayınları.

"İstanbul gazetecilerinden bazıları tarafindan varid olan istirhamnâmedir", Kara Sinan, Say1: 6, 8 Temmuz 1875 (26 Haziran 1291/ 4 Cemaziyelahir 1292), s.3.

“İstanbuldan telgraf", Kara Sinan, Sayı: 3, 17 Haziran 1875 (20 Cemaziyelevvel 1292 / 12 Haziran 1291), s.4.

“İzmirden Mektup”, Hayal, Say1: 165, 6 Temmuz 1875 (24 Haziran 1291), s. 3.

Kara Sinan, Sayı: 1, 4 Haziran 1875 (29 Rebülahir 1292 / 22 Mayıs 1291), s.1.

Kara Sinan, Sayı: 7, 15 Temmuz 1875 (3 Temmuz 1291 / 11 Cemaziyelahir 1292), s.1-2. 